\title{
DIAGENETIC EVOLUTION OF INCISED CHANNEL SANDSTONES: IMPLICATIONS FOR RESERVOIR CHARACTERISATION OF THE LOWER CARBONIFEROUS MARAR FORMATION, GHADAMES BASIN, WESTERN LIBYA
}

\author{
S. Fröhlich ${ }^{a^{*}}$, J. Redfern ${ }^{\mathrm{a}}$, L. Petitpierre ${ }^{\mathrm{a}}$, J.D. Marshall, \\ M. Power' and P.V. Grech ${ }^{\mathrm{d}}$
}

This paper assesses the diagenetic history of potential fluvial hydrocarbon reservoir rocks deposited within incised valley systems of the Lower Carboniferous Marar Formation in western Libya. Outcrop data were collected in the Tinedhan Anticline, located at the southern margin of the Ghadames Basin. Four discrete intervals with channelized sandstones were identified in a section dominated by alternating offshore mudstones and shallow-marine clastics. The incised channels were cut during major sea-level lowstands, and filled by fluvial sandstone packages up to $50 \mathrm{~m}$ thick. Fiftyeight samples from four different localities, representing three lowstand systems tracts, were analysed to obtain a statistically meaningful mineralogical and compositional dataset.

In addition to burial compaction, three main diagenetic events influenced the reservoir quality of the sandstones. Firstly, early eodiagenesis involved kaolinitization of plagioclase grains. This began before subsequent calcite cementation, probably as a result of flushing by meteoric porewaters. The deformation of kaolinite during later compaction resulted in the formation of pseudomatrix which further reduced porosity and permeability. Kaolinite is commonly transformed to illite at temperatures above $140^{\circ} \mathrm{C}$ in the presence of K-feldspar. Although K-feldspar was recorded in the samples, no illite was observed, suggesting that the Lower Carboniferous strata in the study area were not buried in excess of approximately $3.5 \mathrm{~km}$.

The second diagenetic phase was the precipitation of calcite cement, present either dispersed throughout the sandbodies or as concretions up to $2 \mathrm{~m}$ across, in both cases reducing reservoir

a North Africa Research Group, School of Earth, Atmospheric and Environmental Sciences, The University of Manchester, Oxford Road, Manchester MI3 9PL.

b Earth and Ocean Sciences, University of Liverpool, L69 3BX.

c formerly Intellection UK Ltd. Present address: SGS UK Ltd, Rossmore Business Park, Ellesmere Port, Cheshire $\mathrm{CH} 65$ 3EN.

d formerly Woodside Energy (N.A.) Ltd. Tripoli, Libya. Present address: PETROM S.A., I Piata Eroilor, 100316 Ploiesti, Prahova, Romania.

* Corresponding author. email: sebo.froe@gmx.de Present address: Statoil ASA, Mølnholtet 42, PO Box 40, 948I Harstad, Norway. quality. The high intergranular volumes (IGV) of calcite-cemented sandstones (ranging between $35 \%$ and $40 \%$ ) suggest that cementation occurred at burial depths of $<500 \mathrm{~m}$. Sandstones without calcite cement have lower IGV of between $17 \%$ and $25 \%$ as a result of mechanical and chemical compaction. Stable $\mathrm{C}$ and $\mathrm{O}$ isotope analysis of the calcite cement also supports precipitation at shallow burial depths, indicating a meteoric pore-water source for the calcite. The third and final diagenetic stage was partial chloritisation of kaolinite during meso-

Key words: Libya, Ghadames Basin, Carboniferous, diagenesis, calcite cement, kaolinite, chlorite. 
diagenesis. The elevated temperatures required for this transformation indicate burial to a minimum depth of approximately $2.5 \mathrm{~km}$, which is consistent with the compaction data.

Despite these diagenetic effects, the fluvial sandstones have an average porosity of $12 \%$, with a range from $0.5 \%$ up to $25 \%$. Permeability measurements on four sandstone samples indicate that the development of pseudomatrix did not reduce permeability significantly.

\section{INTRODUCTION}

The Murzuq, Ghadames and Illizi Basins of western Libya and eastern Algeria, all of which are important petroleum provinces (e.g. Boote et al., 1998), have proven major petroleum reservoirs in CambroOrdovician, Silurian and Devonian sandstones (e.g. Abouessa and Morad, 2009; Alem et al., 1998; Davidson et al., 2000; Echikh, 1998). Carboniferous deposits have largely been neglected as exploration targets due to the perceived limited reservoir distribution and quality. The only significant Carboniferous discovery to-date is the Al Atshan field in western Libya (Belhaj, 2000; Abugares, 2003) in which oil and gas is present in Lower Carboniferous reservoir rocks. However, the recent identification of incised channels containing fluvial sandstone units up to $50 \mathrm{~m}$ thick in outcropping Lower Carboniferous rocks in the southern Ghadames Basin (Fröhlich et al., in press) may indicate the presence of potentially important Carboniferous reservoirs.

The quality of these sandstones is variable as a result of the presence of diagenetic pore-filling cements. This study investigates the diagenesis of these fluvial sandstones which were deposited in largescale channels following incision associated with sealevel lowstand. As patterns of early diagenetic alteration in sandstones are strongly dependent on near-surface pore-water chemistry and the composition of detrital grains (Morad et al., 2000), the depositional environment of the sample localities is described before the diagenetic alterations are evaluated.

The objects of this paper are: (1) to provide a case study of diagenetic alteration observed in fluvial channel systems which incise into marine shelf deposits; (2) to evaluate the timing of calcite cementation and clay-mineral formation and to assess resulting effects on porosity; (3) to determine the source of the calcite cement; and (4) to use the diagenetic history to assess the burial history of Lower Carboniferous rocks in the southernmost Ghadames Basin.

Diagenetic regimes are divided into eodiagenesis $\left(0-2 \mathrm{~km}\right.$ depth and $\left.<70^{\circ} \mathrm{C}\right)$ and mesodiagenesis $(>2$ $\mathrm{km}$ depth and $>70^{\circ} \mathrm{C}$ ). The former regime is mostly influenced by depositional facies, climate, detrital composition and relative sea-level changes, while the latter is mainly controlled by temperature, pressure, formation water chemistry and eogenetic alterations (Morad et al., 2000).

\section{GEOLOGICAL BACKGROUND}

The study area is located in the Tinedhan Anticline on the southern margin of the Ghadames Basin in western Libya (Fig. 1). This intracratonic sag basin, which extends into Algeria and Tunisia, contains up to $3000 \mathrm{~m}$ of Cambrian to Carboniferous deposits, unconformably overlain by Triassic to Cenozoic strata (Boote et al., 1998; Underdown and Redfern, 2008). Carboniferous strata reach a maximum thickness of over $1200 \mathrm{~m}$ in the subsurface (Belhaj, 2000) and up to $850 \mathrm{~m}$ at outcrop. Lower Carboniferous deposits in western Libya are divided into the Marar Formation (upper Tournaisian to top-Viséan) and the Assedjefar Formation (Serpukhovian) (Fig. 2), which are separated by a regional stromatolitic horizon, the Collenia Beds (Grubic et al., 1991; Lelubre, 1948; Lelubre, 1952; Mergl and Massa, 2000). Recent outcrop and subsurface studies have recognised four facies associations: offshore mudstones, shallowmarine clastics, fluvial sandstones and marine carbonates (Fröhlich et al., in press).

Deposition during the Early Carboniferous took place on a continental shelf which extended over most of North Africa and was bound by a continental landmass to the south and Palaeotethys to the north (Guiraud et al., 2005). The palaeolatitudinal position of Libya during the Early Carboniferous was probably between $40^{\circ}$ and $30^{\circ}$ south (Scotese, 2000) and palaeoclimatic reconstructions suggest that the climate was warm and humid (Raymond et al., 1985; Wright, 1990).

\section{SEDIMENTOLOGY AND SEQUENCE STRATIGRAPHY}

The base of the Marar Formation, which equates to the base of the Carboniferous, is a prominent regional unconformity interpreted to be a type 2 sequence boundary (Carr, 2002). The Lower Carboniferous of western Libya (Marar and Assedjefar Formations) can be divided into five depositional sequences (Fröhlich et al., in press). Transgressive systems tracts (TST) and highstand systems tracts (HST) dominantly consist of alternating offshore mudstones and shallowmarine clastics. HSTs are made up of thickening- and coarsening-upward cycles, typically showing a succession from hummocky cross-stratified sandstones to wave-ripple sandstones to multi- 

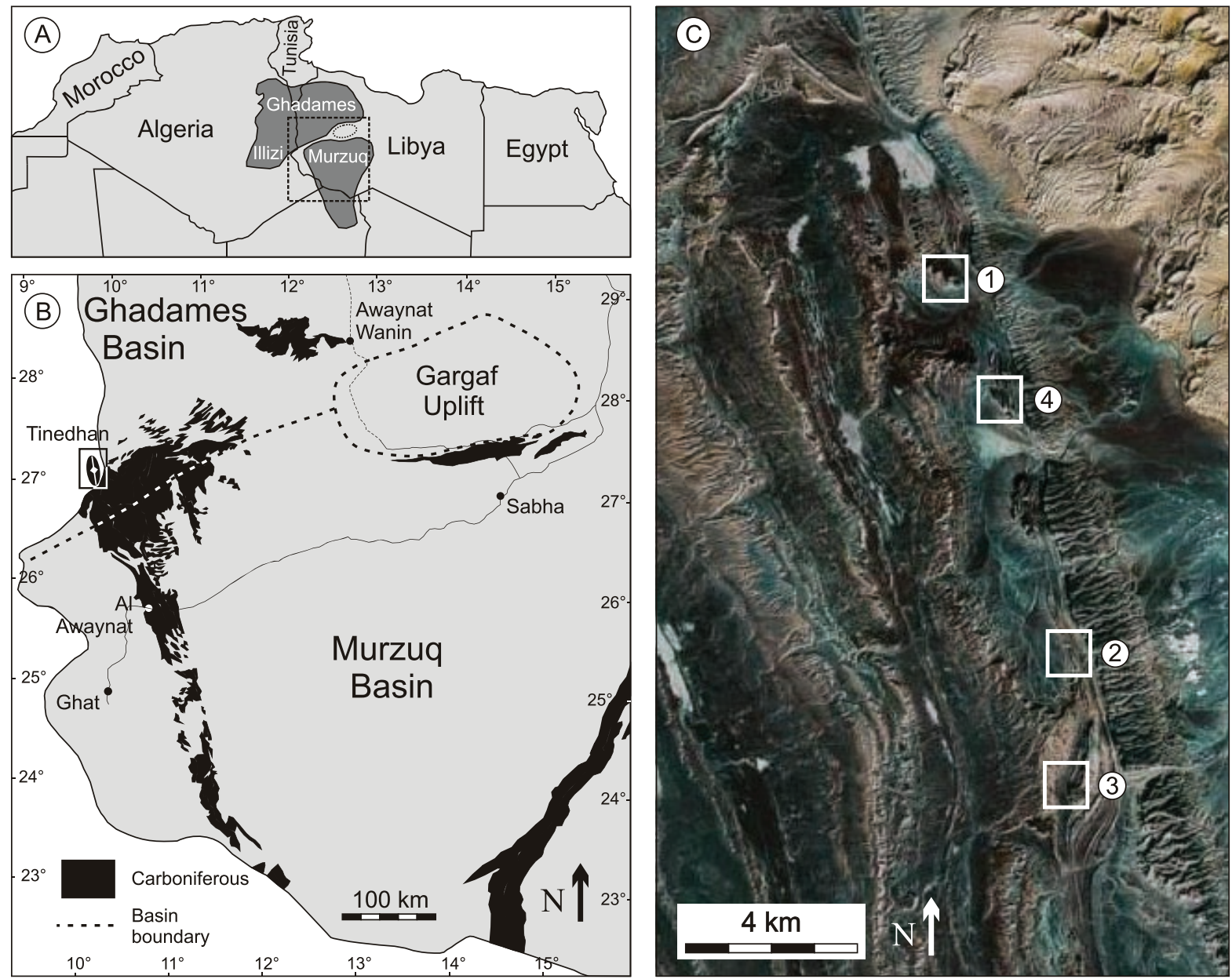

Fig. I. Location maps of the study area. (A) Location map of the Ghadames and Murzuq Basins in North Africa. (B) Carboniferous outcrops in western Libya (modified from the I:I,000,000 geological map of Libya), showing the location of the Tinedhan Anticline. (C) Satellite image of the Tinedhan Anticline (Google Earth) with numbered sample locations.

directional cross-stratified sandstones, which are interpreted as shallowing-upward cycles from storminfluenced to shoreface environments. Bioclastic limestone layers up to $0.5 \mathrm{~m}$ thick are rarely present. The stacking pattern of TSTs commonly shows thinning-upward sandstone packages, contrasting with the thickening-upward pattern in the HSTs.

Four lowstand systems tracts (LST 2 to LST 5) occur within the Lower Carboniferous strata. No unit LST 1 was recognised in the study area and the basal sequence consists only of TST 1 and HST 1 . LSTs 2 to 5 contain distinctive lenticular sandstone bodies (1.5-50 $\mathrm{m}$ thick and 40-1500 $\mathrm{m}$ wide) with erosive bases (Fig. 3), comprising fine-grained unidirectional cross-bedded sandstones. The presence of large-scale cross-bedding, erosive bases with rip-up clasts and the lack of bioturbation or marine fauna suggests a fluvial origin. These channel sandstones incise into the underlying marine shelf succession which consists of alternating offshore mudstones, storm deposits and shoreface deposits. The channels are interpreted to be incised fluvial valleys which developed during subaerial exposure of the western Libyan shelf. The erosive base of each major channel is interpreted to be a sequence boundary, forming the base of a LST. The upper boundary is a marine flooding surface (Fröhlich et al., in press).

The sandstones sampled for this diagenetic study were all deposited within these fluvial channels.

\section{SAMPLE LOCATIONS}

The study was conducted at the NNW-SSE trending Tinedhan Anticline (Fig. 1). This structure, located at $\mathrm{N} 27^{\circ} 07^{\prime}$ E009 56', is exposed in an area approximately $30 \mathrm{~km}$ long and $10 \mathrm{~km}$ wide. The crest of the anticline has been eroded, and late Tournaisian to Moscovian deposits of the Marar, Assedjefar and Dembaba Formations outcrop along the flanks. Four locations (Fig. 1c) were sampled within channels which were interpreted to form LSTs 2, 4 and 5. LST 3 was not sampled due to poor outcrop quality.

Locality 1 (N $27^{\circ} 13$ '5.24" E 9०55'49.27”): At this locality, a $17 \mathrm{~m}$ thick sandstone body is exposed within a large channel. Sandstones are thickly bedded, with poorly preserved large-scale cross-bedding and a few 


\begin{tabular}{|c|c|c|c|c|}
\hline PER. & & STAGE & Ma & FORMATION \\
\hline \multirow{4}{*}{$\begin{array}{l}\frac{0}{3} \\
\frac{0}{0} \\
4\end{array}$} & \multirow{5}{*}{ 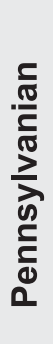 } & Gzhelian & \multirow{3}{*}{$\begin{array}{l}299 \\
304\end{array}$} & \multirow{3}{*}{ Tiguentourine Fm } \\
\hline & & & & \\
\hline & & Kasimovian & & \\
\hline & & Moscovian & \multirow{2}{*}{$\begin{array}{l}307 \\
312\end{array}$} & \multirow{2}{*}{ Dembaba Fm } \\
\hline & & Bashkirian & & \\
\hline & \multirow{3}{*}{ 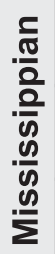 } & Serpukhovian & \multirow{2}{*}{$\begin{array}{l}318 \\
326\end{array}$} & Assedjefar Fm \\
\hline & & Visean & & Marar Fm \\
\hline & & Tournaisian & \multirow{2}{*}{$\begin{array}{l}345 \\
359\end{array}$} & \\
\hline & & & & \\
\hline
\end{tabular}

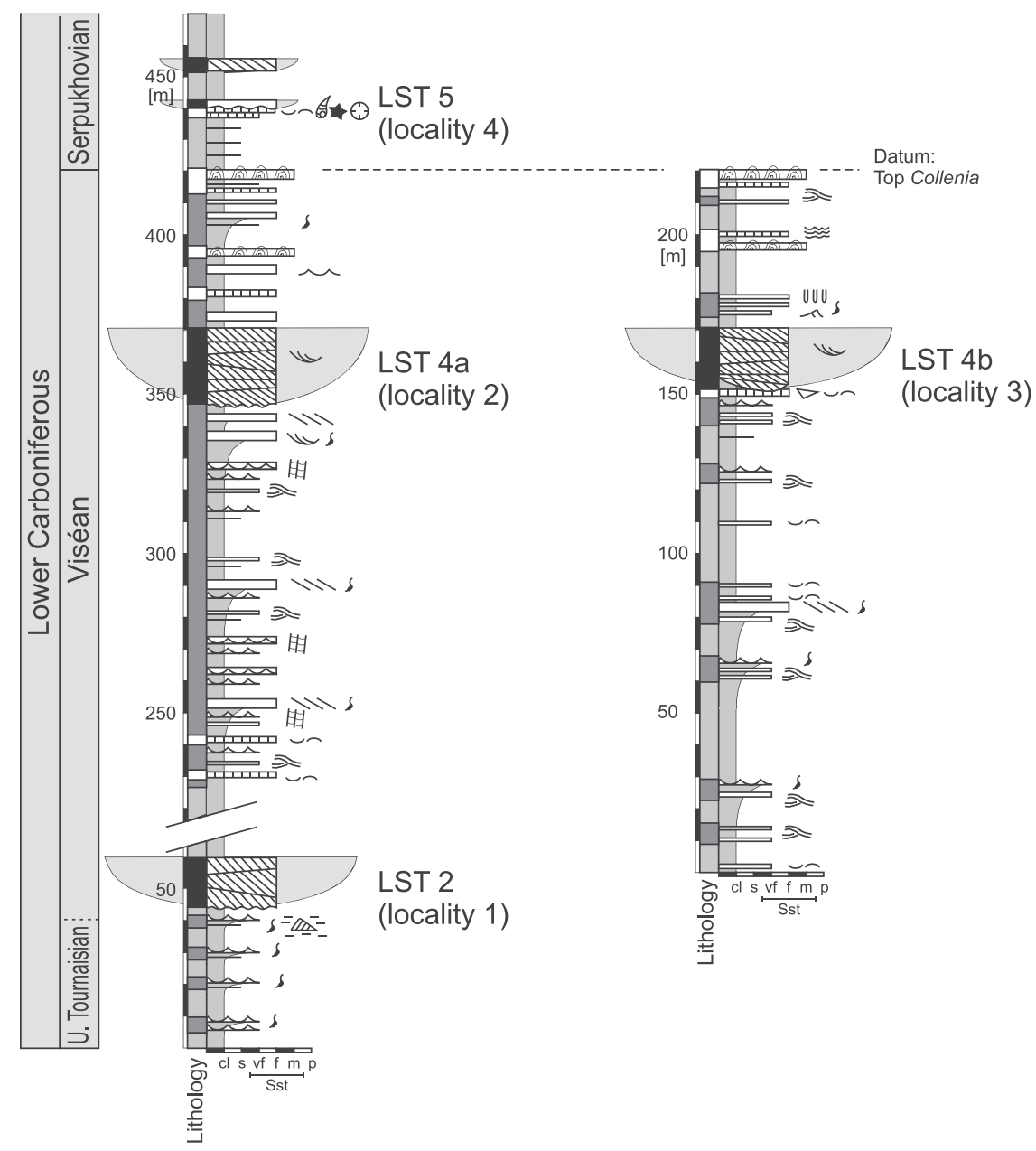

Fig. 2. Carboniferous stratigraphy (Menning et al., 2006) and age of formations in Libya.

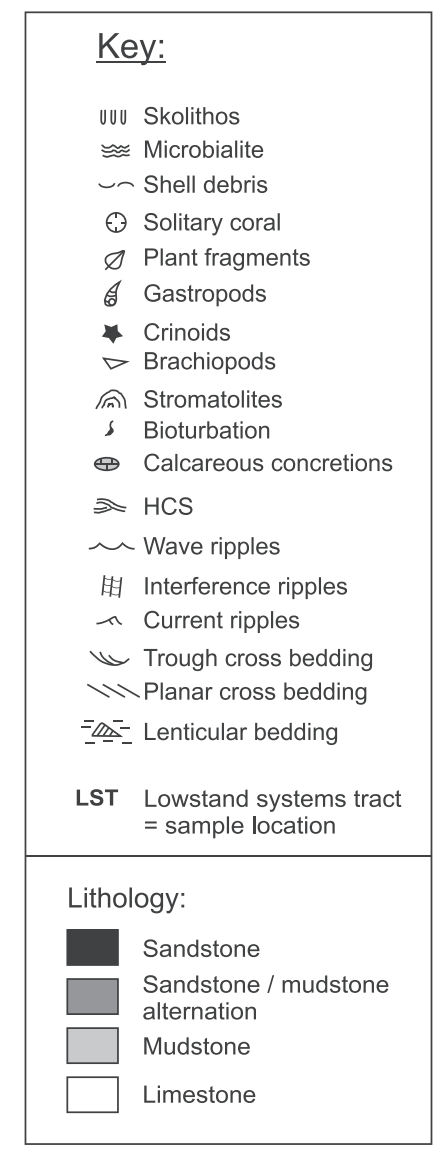

Fig. 3. Composite sedimentary logs indicating the stratigraphic position of fluvial channel sandbodies which were sampled for this study.

rip-up clasts. The erosive base cuts into a mudstonedominated succession containing thinly-bedded sandstone layers which show abundant ripple crosslaminations and some bioturbation. The channel occurs in the lower Marar Formation, forming the base of LST 2. Thirteen representative samples were taken from the base to the top of the sandstone (Table 1).
Locality 2 (N 277'54.66” E 957'43.54”): Here, a channel within the upper Marar Formation contains a sandbody up to $25 \mathrm{~m}$ thick with abundant largescale cross-bedding. Sandstones are friable; concretions up to $2 \mathrm{~m}$ wide occur in the centre of the channel, and are on average spaced every $5 \mathrm{~m}$ laterally. Patches with abundant grapestone 

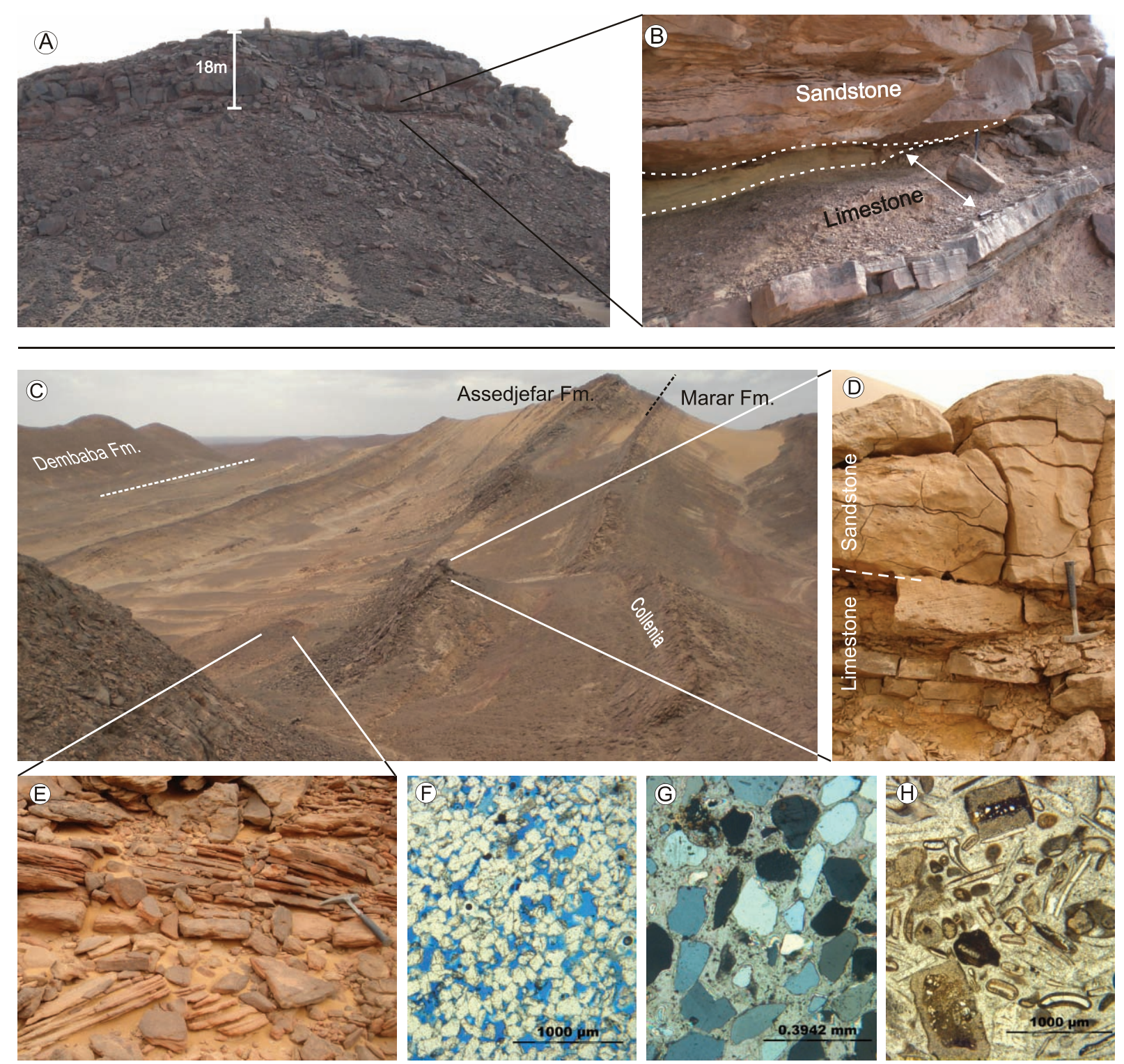

Fig. 4. Field photographs from the study area and photomicrographs. A. Sample location 3: $18 \mathrm{~m}$ thick channel sandstone interpreted as LST 4. B. Detail of the erosive base of the sandstone in A below which is a ca. $40 \mathrm{~cm}$ thick limestone. C. Field view of the Carboniferous section on the eastern flank of the Tinedhan anticline; two channel sandstones in the centre represent sample location 4 (see Fig. Ic). D. Detail of C showing a ca. I.5 $\mathrm{m}$ thick channel sandstone (LST 5) in erosional contact with a shallow-marine limestone. E. Detail of C showing large-scale planar cross-bedding in channel sandstones. F. Photomicrograph of a porous sandstone from the location in E; grey = porosity. G. Photomicrograph (crossed nicols) of a sample from the calcite cemented sandstone shown in the upper part of $D$. H. Photomicrograph of a sample from the limestone in the lower part of $D$; bioclasts in this grainstone are dominated by shell fragments, coated grains and crinoid ossicles.

concretions, measuring several $\mathrm{mm}$ to $2 \mathrm{~cm}$ across (sensu McBride and Milliken, 2006) were scattered throughout the sandstone. The channel incises into mudstones that contain intercalated rippled and smallscale cross-bedded sandstone layers. This channel is correlated to LST 4. Sixteen samples were collected from the sandstone and three samples were derived from concretions (JA 901-16 to 18, Table 1).

Locality 3 (N 27622.32” E 9 57’36.57’'): An $18 \mathrm{~m}$ thick channel sandstone at this location also correlates to LST 4 (Fig. 4a). The underlying succession consists of alternating thick mudstone layers and thin to medium bedded sandstones with HCS and cross-lamination. The fluvial channel cuts down to an approximately $0.3 \mathrm{~m}$ thick bioclastic carbonate layer with abundant brachiopods (Fig. 4b). Thirteen samples were collected from the base to the top of the channel, and two samples were taken from the underlying limestone.

Locality 4 (N 2711'38.56” E 956’38.50”): This locality is within the lower Assedjefar Formation and correlates with LST 5 (Fig. 4c). A $1.5 \mathrm{~m}$ thick, hard sandstone occurs within a channel. Faint outlines of metre-scale concretions were observed, picked out by 
Table I. QEMSCAN ${ }^{\circledR}$ data, intergranular volume (IGV) and modal composition of sandstone samples. Qtz, quartz; K-Fsp, K-feldspar; Plag, plagioclase; Misc, miscellaneous.

\begin{tabular}{|c|c|c|c|c|c|c|c|c|c|c|c|c|c|c|c|c|c|c|c|}
\hline \multirow[b]{2}{*}{ Location } & \multirow[b]{2}{*}{ Sample No. } & \multirow[b]{2}{*}{ Qtz } & \multirow[b]{2}{*}{ K-Fsp } & \multirow[b]{2}{*}{ Plag } & \multirow[b]{2}{*}{ Calcite } & \multirow[b]{2}{*}{ Kaolinite } & \multirow[b]{2}{*}{ Chlorite } & \multirow[b]{2}{*}{ Siderite } & \multirow[b]{2}{*}{ Gypsum } & & & & & & & & Modal c & imposit & \\
\hline & & & & & & & & & & Pyrite & $\begin{array}{l}\text { Fe/Mn } \\
\text { oxides }\end{array}$ & Alunite & Misc & Porosity & $\begin{array}{l}\text { av. grain- } \\
\text { size [ } \mu \mathrm{m}]\end{array}$ & IGV & $\mathrm{Q}$ & $\mathrm{F}$ & 느 \\
\hline 1 & T 10-3 & 51.37 & 0.24 & 0.02 & 0.02 & 26.22 & 0.49 & 0.01 & 0.03 & 0.07 & 0.00 & 0.50 & 2.24 & 18.77 & 81 & 19.3 & 99.5 & 0.5 & \\
\hline 1 & Т 10-8 & 4.92 & 0.28 & 0.03 & 1.31 & 23.35 & 2.28 & 0.03 & 1.32 & 0.49 & 0.01 & 0.36 & 2.15 & 13.47 & 80 & 16.5 & 99.4 & 0.6 & 0 \\
\hline 1 & T $10-11$ & 9.84 & 0.04 & 0.01 & 1.60 & 13.79 & 0.23 & 0.16 & 1.71 & 0.39 & 0.20 & 28.25 & 1.04 & 2.72 & 177 & & 98.9 & & 1 \\
\hline 1 & Т $10-12$ & .93 & 0.01 & 0.01 & 0.09 & 9.19 & 1.81 & 0.05 & 0.01 & 0.0 & 0.0 & 0.01 & 0.1 & 23.76 & 173 & 23.9 & 100.0 & & 0 \\
\hline 1 & T $10-13$ & 65.55 & 0.12 & 0.01 & 1.75 & 8.81 & 0.11 & 0.02 & 0.39 & 0.0 & 0.0 & 4.83 & 0.80 & 17.53 & 187 & 24.5 & 97.8 & 0.2 & 2 \\
\hline 1 & T 10-14 & 67.85 & 0.01 & 0.02 & 1.13 & 5.22 & 0.57 & 0.02 & 0.01 & 0.00 & 0.0 & 0.01 & 0.47 & 24.67 & 200 & 25.8 & 98.0 & 0.0 & 2 \\
\hline 1 & T $10-15$ & 70.67 & 0.01 & 0.01 & 0.12 & 2.17 & 4.00 & 0.73 & 0.00 & 0.00 & 0.44 & 0.02 & 0.56 & 21.27 & 205 & 21.4 & 99.0 & 0.0 & 1 \\
\hline 1 & T 10-16 & 69.37 & 0.01 & 0.04 & 3.23 & 3.30 & 2.81 & 0.04 & 0.03 & 0.00 & 0.00 & 0.01 & 0.44 & 20.73 & 198 & 24.0 & 98.9 & 0.1 & 1 \\
\hline 1 & T 10-17 & 66.31 & 0.01 & 0.03 & 1.64 & 6.16 & 2.52 & 0.13 & 0.00 & 0.00 & 0.03 & 0.02 & 0.43 & 22.73 & 178 & 24.4 & 99.0 & 0.0 & 1 \\
\hline 1 & T 10-18 & 77.77 & 0.23 & 0.03 & 0.34 & 11.48 & 0.83 & 0.29 & 0.65 & 0.70 & 0.06 & 4.39 & 0.78 & 2.45 & 162 & 7.8 & 98.7 & 0.3 & 1 \\
\hline 1 & T 10-20 & 66.16 & 0.05 & 0.01 & 0.29 & 9.66 & 0.93 & 0.06 & 0.31 & 0.12 & 0.06 & 3.92 & 0.85 & 17.58 & 180 & 22.1 & 99.9 & 0.1 & 0 \\
\hline 1 & T 10-21 & 69.94 & 0.01 & 0.00 & 0.05 & 0.80 & 1.83 & 1.49 & 0.01 & 0.00 & 0.30 & 0.01 & 0.60 & 24.95 & 216 & 25.0 & 98.0 & 0.0 & 2 \\
\hline 1 & T 10-22 & 66.98 & 0.25 & 0.03 & 4.70 & 8.26 & 0.28 & 0.14 & 1.07 & 0.18 & 0.09 & 3.99 & 1.16 & 12.87 & 192 & 22.6 & 98.6 & 0.4 & 1 \\
\hline 1 & Average & 64.74 & 0.10 & 0.02 & 1.25 & 9.88 & 1.44 & 0.24 & 0.43 & 0.16 & 0.09 & 3.56 & 0.89 & 17.19 & 171 & 22.4 & 98.9 & 0.2 & 0.9 \\
\hline $\begin{array}{l}2 \\
2\end{array}$ & $\begin{array}{l}\text { JA 901-1 } \\
\text { JA 901-2 }\end{array}$ & $\begin{array}{l}66.29 \\
62.48\end{array}$ & $\begin{array}{l}3.31 \\
5.48\end{array}$ & $\begin{array}{l}0.03 \\
0.01\end{array}$ & $\begin{array}{l}3.44 \\
0.05\end{array}$ & $\begin{array}{r}10.29 \\
5.46\end{array}$ & $\begin{array}{l}0.35 \\
4.98\end{array}$ & $\begin{array}{l}0.03 \\
0.75\end{array}$ & $\begin{array}{l}0.00 \\
0.00\end{array}$ & $\begin{array}{l}0.00 \\
0.00\end{array}$ & $\begin{array}{l}0.01 \\
0.37\end{array}$ & $\begin{array}{l}0.04 \\
0.09\end{array}$ & $\begin{array}{l}0.64 \\
0.52\end{array}$ & $\begin{array}{l}15.57 \\
19.79\end{array}$ & $\begin{array}{l}193 \\
175\end{array}$ & $\begin{array}{l}19.0 \\
19.9\end{array}$ & $\begin{array}{l}94.7 \\
91.4\end{array}$ & $\begin{array}{l}4.3 \\
7.6\end{array}$ & $\begin{array}{l}1 \\
1\end{array}$ \\
\hline 2 & JA 901-3 & $\begin{array}{l}73.40 \\
73.33\end{array}$ & $\begin{array}{l}5.40 \\
2.82\end{array}$ & 0.01 & $\begin{array}{l}1.78 \\
\text {. }\end{array}$ & $\begin{array}{l}5.40 \\
2.44\end{array}$ & 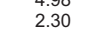 & 0.76 & 0.00 & 0.00 & 0.21 & 0.05 & 0.55 & 15.74 & 221 & 17.6 & $\begin{array}{l}91.4 \\
95.8\end{array}$ & $\begin{array}{l}3.0 \\
3.2\end{array}$ & 1 \\
\hline 2 & JA 901-4 & 64.54 & 4.29 & 0.01 & 0.58 & 6.49 & 4.22 & 1.14 & 0.00 & 0.0 & 0.5 & 0.04 & 0.44 & 17.69 & 171 & 18.3 & 93.3 & 5.7 & 1 \\
\hline 2 & JA 901-5 & 69.73 & 1.09 & 0.01 & 0.06 & 4.29 & 0.04 & 0.00 & 0.00 & 0.0 & 0.0 & 0.0 & 0.5 & 24.19 & 199 & 24. & 98.4 & 1.6 & \\
\hline 2 & JA 901-6 & 69.86 & 2.71 & 0.02 & 4.14 & 3.73 & 0.80 & 0.15 & 0.00 & 0.0 & 0.0 & 0.0 & 0.2 & 18.24 & 207 & 22.4 & 95.7 & 3.3 & 1 \\
\hline 2 & JA 901-7 & 68.62 & 2.23 & 0.01 & 2.89 & 2.06 & 4.78 & 0.49 & 0.00 & 0.01 & 0.0 & 0.02 & 0.32 & 18.5 & 183 & 21.5 & 96.3 & 2.7 & \\
\hline 2 & JA 901-8 & 50.46 & 10.21 & 0.04 & 2.17 & 15.19 & 0.12 & 0.02 & 0.00 & 0.0 & 0.0 & 0.07 & 1.45 & 20.2 & 134 & 22.5 & 82.6 & 16.4 & 1 \\
\hline 2 & JA 901-10 & 53.79 & 7.93 & 0.05 & 9.92 & 6.99 & 5.06 & 1.75 & 0.00 & 0.0 & 0.6 & 0.07 & 1.06 & 12.74 & 137 & 22.7 & 86.1 & 11.9 & 2 \\
\hline 2 & JA 901-11 & 54.43 & 10.67 & 0.01 & 0.89 & 12.02 & 0.61 & 0.01 & 0.00 & 0.00 & 0.00 & 0.12 & 1.07 & 20.18 & 149 & 21.2 & 82.6 & 15.4 & 2 \\
\hline 2 & JA 901-12 & 63.17 & 5.57 & 0.05 & 12.76 & 4.36 & 0.04 & 0.02 & 0.00 & 0.00 & 0.01 & 0.03 & 0.39 & 13.57 & 176 & 26.4 & 91.8 & 8.2 & 0 \\
\hline 2 & JA 901-13 & 49.56 & 13.90 & 0.01 & 0.10 & 14.70 & 2.47 & 0.52 & 0.00 & 0.00 & 0.19 & 0.15 & 1.47 & 16.95 & 126 & 17.2 & 77.6 & 21.4 & 1 \\
\hline 2 & JA 901-14 & 58.45 & 9.67 & 0.01 & 0.09 & 10.82 & 0.92 & 0.01 & 0.01 & 0.00 & 0.01 & 0.09 & 1.20 & 18.73 & 159 & 18.9 & 85.3 & 13.7 & 1 \\
\hline 2 & JA 901-16 & 46.43 & 11.08 & 0.02 & 34.03 & 5.61 & 0.20 & 0.09 & 0.15 & 0.00 & 0.23 & 0.05 & 0.81 & 1.30 & 123 & 35.5 & 80.7 & 19.3 & 0 \\
\hline 2 & JA 901-17 & 40.63 & 12.69 & 0.02 & 36.77 & 7.29 & 0.16 & 0.03 & 0.00 & 0.00 & 0.03 & 0.05 & 0.64 & 1.69 & 114 & 38.5 & 76.2 & 23.8 & 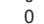 \\
\hline 2 & JA 901-18 & 42.87 & 11.66 & 0.02 & 35.87 & 6.96 & 0.16 & 0.02 & 0.23 & 0.00 & 0.02 & 0.06 & 0.79 & 1.37 & 112 & 37.5 & 78.6 & 21.4 & 0 \\
\hline 2 & Average & 58.41 & 7.21 & 0.02 & 9.10 & 7.42 & 1.70 & 0.36 & 0.03 & 0.00 & 0.15 & 0.06 & 0.76 & 14.79 & 161 & 24.0 & 87.9 & 11.2 & 0.8 \\
\hline 3 & JA 951-2 & 61.22 & 4.51 & 0.17 & 28.69 & 2.74 & 0.31 & 0.05 & 0.43 & 0.02 & 0.03 & 0.03 & 0.39 & 1.40 & 168 & 30.55 & 92.4 & 6.6 & 1 \\
\hline 3 & & & 12.07 & 0.71 & 12.3 & 8.02 & 0.58 & & 0.00 & & & & 0.91 & 17.62 & 116 & 30.06 & 78.3 & 20.7 & 1 \\
\hline 3 & JA 951-4 & 55.10 & 8.06 & 0.30 & 20.7 & 5.03 & 0.30 & 0.07 & 0.00 & 0. & 0.04 & 0.05 & 0.68 & 9.56 & 137 & 30.40 & 86.8 & 13.2 & 0 \\
\hline 3 & JA 951 & 42.15 & 11.22 & 2.89 & 38.3 & 3.75 & 0.11 & 0.05 & 0.00 & 0. & & 0.03 & 0.51 & 0.92 & 116 & 39.30 & 73.4 & 23.6 & 3 \\
\hline 3 & JA 951-8 & 49.86 & 8.06 & 2.48 & 35.6 & 2.05 & 0.16 & 0.09 & 0.0 & 0. & 0.0 & 0.02 & 0.43 & 1.21 & 123 & 36.83 & 81.6 & 16.4 & 2 \\
\hline 3 & JA 951-9 & 52.35 & 11.02 & 1.20 & 21.6 & 5.66 & & & 0.0 & 0. & & & 0.68 & 6.08 & 140 & 27.82 & 80.1 & 17.9 & 2 \\
\hline 3 & JA 951-10 & 48.82 & 12.05 & 1.58 & 28.8 & 5.20 & 0.79 & & 0.0 & 0. & 0.04 & 0.07 & 0.73 & 1.75 & 134 & 30.69 & 77.2 & 20.8 & 2 \\
\hline 3 & JA & 51.11 & 10.92 & 1.59 & 1.2 & & & 0.15 & 0.0 & 0. & 0.3 & & 0.80 & 25.42 & 135 & 26.77 & 79.8 & 19.2 & 1 \\
\hline 3 & $951-12$ & 48.77 & 11.41 & 1.82 & 23.1 & 6.19 & & 0.22 & 0.0 & 0. & 0. & & 0.85 & 5. & 134 & 29.19 & 77.7 & 20.3 & 2 \\
\hline 3 & JA & 48.29 & 12.55 & 1.79 & 18.2 & 51 & & 0.1 & 0.0 & & & 0.0 & 0.5 & & 124 & 27.01 & 75.6 & 21.4 & 3 \\
\hline 3 & JA & 41.15 & 14.27 & 1.96 & 32.2 & 8.21 & 0.11 & 0.0 & 0.0 & 0. & 0. & 0.05 & 1.1 & 0. & 118 & 33.18 & 69.7 & 26.3 & 4 \\
\hline 3 & & 50.72 & 11.38 & 0.7 & 19.5 & 7.34 & 0.5 & $0 . C$ & 0.0 & 0. & & 0.06 & 1.0 & 8.5 & 135 & 28.20 & 79.6 & 18.4 & 2 \\
\hline 3 & & 48.57 & 10.25 & 0.70 & 28.3 & & 0.27 & 0. & 0.0 & & & & & 5.1 & 119 & 33.50 & 80.6 & 7.4 & 2 \\
\hline 3 & Average & 49.66 & 10.60 & 1.38 & 23.79 & 5.87 & 0.51 & 0.10 & 0.04 & 0.00 & 0.08 & 0.05 & 0.75 & 7.15 & 131 & 31.04 & 79.4 & 18.6 & 1.9 \\
\hline 4 & JA 1-260a & 44.24 & 7.25 & 8.62 & 37.77 & 0.94 & 0.08 & 0.04 & 0.10 & 0.00 & 0.05 & 0.01 & 0.43 & 0.48 & 137 & 38.4 & 73.1 & 25.9 & 1 \\
\hline 4 & & & & & & & & & & & & & & & & & 74.5 & 24.5 & 1 \\
\hline 4 & JA & 50.7 & 4.57 & 4.94 & 36. & 1.36 & & & 0.02 & & 0.0 & 0.0 & 0.60 & 1.16 & 156 & 37.4 & 83.2 & 14.8 & 2 \\
\hline 4 & JA $1-26$ & 51.64 & 5.42 & 0.87 & 36. & 4.59 & 0.0 & 0.0 & 0.07 & 0.0 & 0.0 & 0.02 & 0.38 & 0.48 & 156 & 36.8 & 88.7 & 10.3 & 1 \\
\hline 4 & JA 1-260e & 48.57 & 5.71 & 6.60 & 36.22 & 0.87 & 0.10 & 0.09 & 0.37 & 0.00 & 0.17 & 0.01 & 0.35 & 0.92 & 143 & 37.5 & 79.3 & 19.7 & 1 \\
\hline 4 & Average & 48.15 & 6.23 & 5.59 & 36.33 & 2.07 & 0.10 & 0.06 & 0.13 & 0.01 & 0.08 & 0.01 & 0.41 & 0.82 & 146 & 37.3 & 79.8 & 19.0 & 1.2 \\
\hline 4 & JA 1-280a & 66.98 & 2.50 & 0.03 & 1.88 & 10.39 & 0.09 & 0.02 & 0.00 & 0.00 & 0.00 & 0.01 & 0.38 & 17.72 & 231 & 19.6 & 96.4 & 3.6 & 0 \\
\hline 4 & & 69.2 & & 0.04 & & & & & & & & & & & 242 & 19.5 & & & 0 \\
\hline 4 & JA 1-28C & 63.71 & 3.40 & 0.03 & 2. & 12.00 & 1. & & 0.00 & 0. & & & & & 217 & 19.3 & 94.4 & 4.6 & 1 \\
\hline 4 & JA 1-280d & 64.49 & 2.30 & 0.01 & 0.7 & 9.7 & 4.7 & 2 & 0.0 & 0. & 0. & & 0. & 16. & 3 & 17.5 & 96.0 & 3.0 & 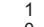 \\
\hline 4 & JA 1-280e & 66.81 & 2.75 & 0.05 & 6.26 & 8.95 & 0.33 & 0.03 & 0.00 & 0. & 0.01 & & 0.35 & 14.43 & 247 & 20.7 & 96.0 & 4.0 & 0 \\
\hline 4 & Average & 66.24 & 2.60 & 0.03 & 2.76 & 9.91 & 1.34 & 0.13 & 0.00 & 0.00 & 0.04 & 0.01 & 0.39 & 16.53 & 230 & 19.3 & 96.0 & 3.6 & 0.4 \\
\hline
\end{tabular}

the weathering profile. The channel incises into a 0.5 $\mathrm{m}$ thick bioclastic limestone, dominantly consisting of shell fragments, crinoid ossicles, gastropods and a few rugose corals. The channel sandstone is overlain by a mudstone $10 \mathrm{~m}$ thick, followed by another smaller channel body about $2 \mathrm{~m}$ thick, containing friable sandstones with large-scale cross-bedding (Fig. 4c). Five samples were collected from the two channel sandstones, and four samples from the limestones.

\section{ANALYTICAL METHODS}

A total of 58 outcrop samples were analysed using the QEMSCAN $^{\circledR}$ system. This automated mineral analysis system is based on a scanning electron microscope (SEM) platform coupled with four silicon drift energydispersive X-ray spectrometers to image and mineralogically map samples using a combination of $\mathrm{X}$-ray and backscattered electron (BSE) signals. Samples were presented to the instrument as polished resin blocks with a $4 \mathrm{~cm}^{2}$ surface area. The acquired mineralogical image of the surface of the sample block has a resolution of $10 \mu \mathrm{m}$. Bulk mineralogy, texture, grain size and porosity were quantified using the collected data.In addition, 46 thin sections were analysed using normal light and cathodoluminescence microscopy.

A JEOL 6400 SEM was used to analyse the texture and habit of clay minerals in 8 carbon-coated sandstone samples, using an accelerating voltage of $15 \mathrm{kV}$.

Stable carbon and oxygen isotopes were analysed at Liverpool University using a VG SIRA 12 isotope ratio mass spectrometer with an online common acid bath preparation device. Isotope ratios are reported with reference to the VPDB international standards. Long-term sample reproducibility is better than 0.1 permil for both carbon and oxygen isotope ratios.

Four sandstone samples were taken with a handheld corer and subsequently analysed for porosity and permeability at Heriot-Watt University using a Helium Gas Expansion Porosimeter MK II and a Nitrogen 

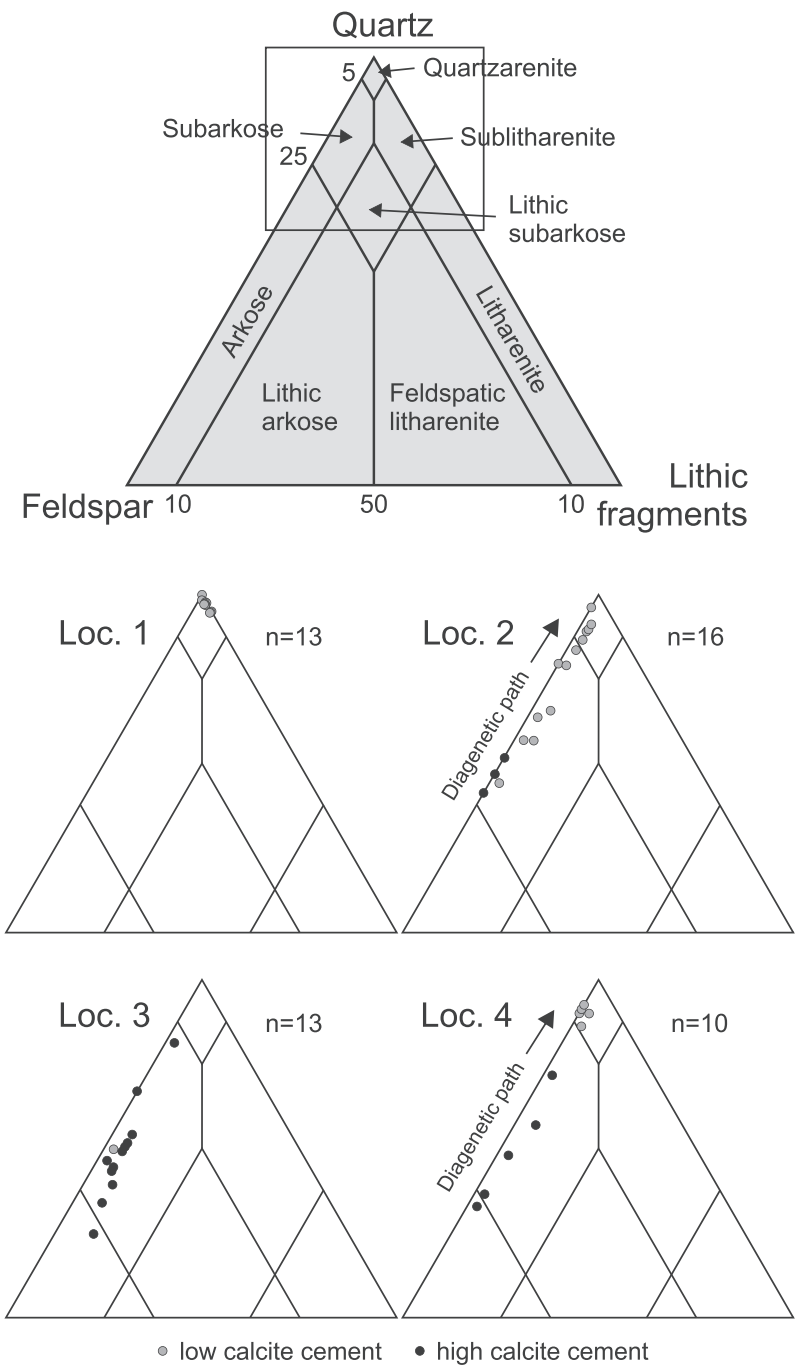

Fig. 5. Modal composition of Lower Carboniferous fluvial sandstones by locality (classification after McBride, 1963). See text for discussion.

Gas Permeameter from Edinburgh Petroleum Development Services Ltd.

\section{RESULTS}

\section{Mineral composition of sandstones}

Framework grains

The average modal composition of all 52 sandstone samples was Q89F10L1, indicating classification as a subarkosic sandstone on a typical QFL plot (McBride, 1963). Variations in composition occur between the sample locations in the different channel systems (Fig. 5). In location 1 , all the samples were quartzarenites with very low feldspar content. At location 3, the samples were subarkoses and one arkose, but no quartzarenites. Locations 2 and 4 show a range from arkose to quartzarenite.

Quartz from all sampled channels had a modal grain size of $161 \mu \mathrm{m}$ (fine sand) (min. $80 \mu \mathrm{m}$; max. $247 \mu \mathrm{m}$ ) (Table 1). The sandstones are sub-angular to rounded and are dominantly very well sorted.
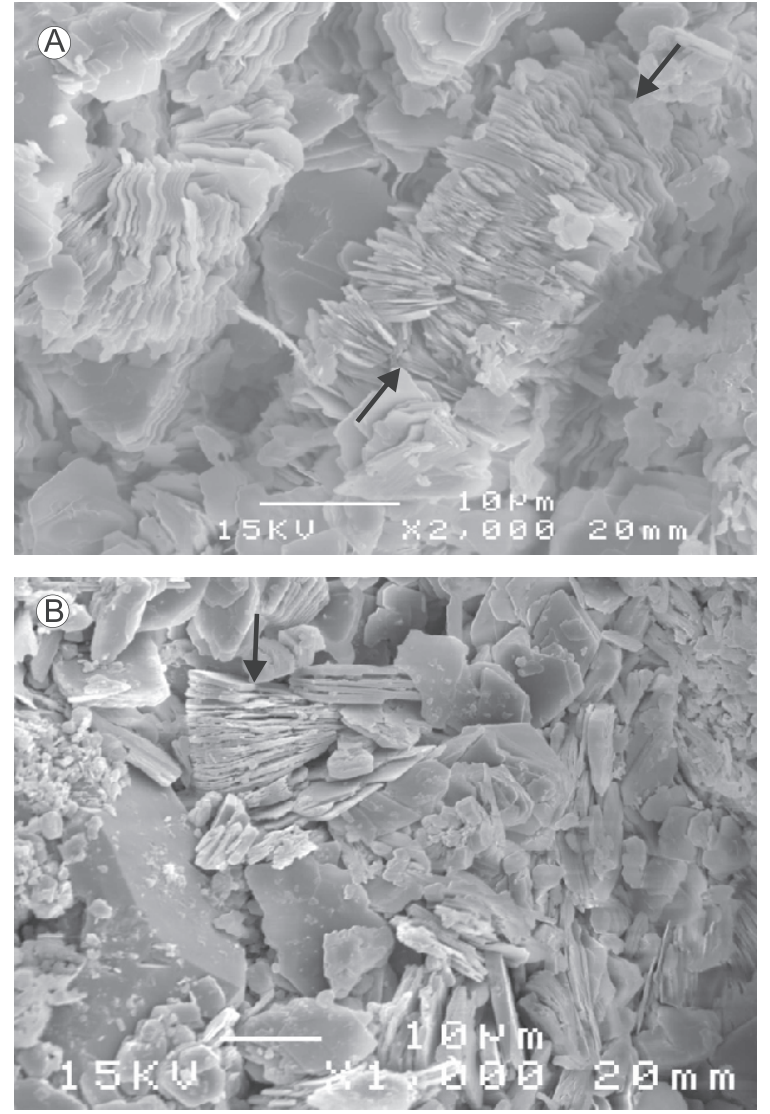

Fig. 6. SEM images of kaolinite habits.

A. Vermicular kaolinite (arrowed); sample JA 90II 4 (location 2). B. Kaolinite booklet (arrowed); sample JA I-280a (location 4).

K-feldspar occurs over an average of $5.7 \%$ of the samples' area (min. 0.0; max. 14.3) and thus dominates over plagioclase which was present over $0.9 \%$ of the area (min. 0.0; max. 8.6). Significant differences occur for example between the hard sandstones of the lower channel in location 4 and the friable sandstones of the upper channel at the same locality (Fig. 4). The former had an average of about $6 \%$ of both K-feldspar and plagioclase, whereas the latter only had about 3\% K-feldspar and no plagioclase.

\section{Clay minerals}

Two types of clay minerals occur in the channel sandstones. The dominant type is kaolinite with an average of $7.4 \%$ (min. 0.8 ; $\max .26 .2$ ) in all 52 measured sandstone samples; chlorite is much less abundant with an average of $1.1 \%$ (min. 0.0 ; max. 5.1). SEM examination shows that kaolinite commonly grew into well-ordered, discrete booklets; vermicular kaolinite occurs only rarely (Fig. 6). QEMSCAN ${ }^{\circledR}$ images (Fig. 7) show that kaolinite mostly occurs scattered throughout the intergranular area. However, in some samples it forms a distinct morphology similar in size to 

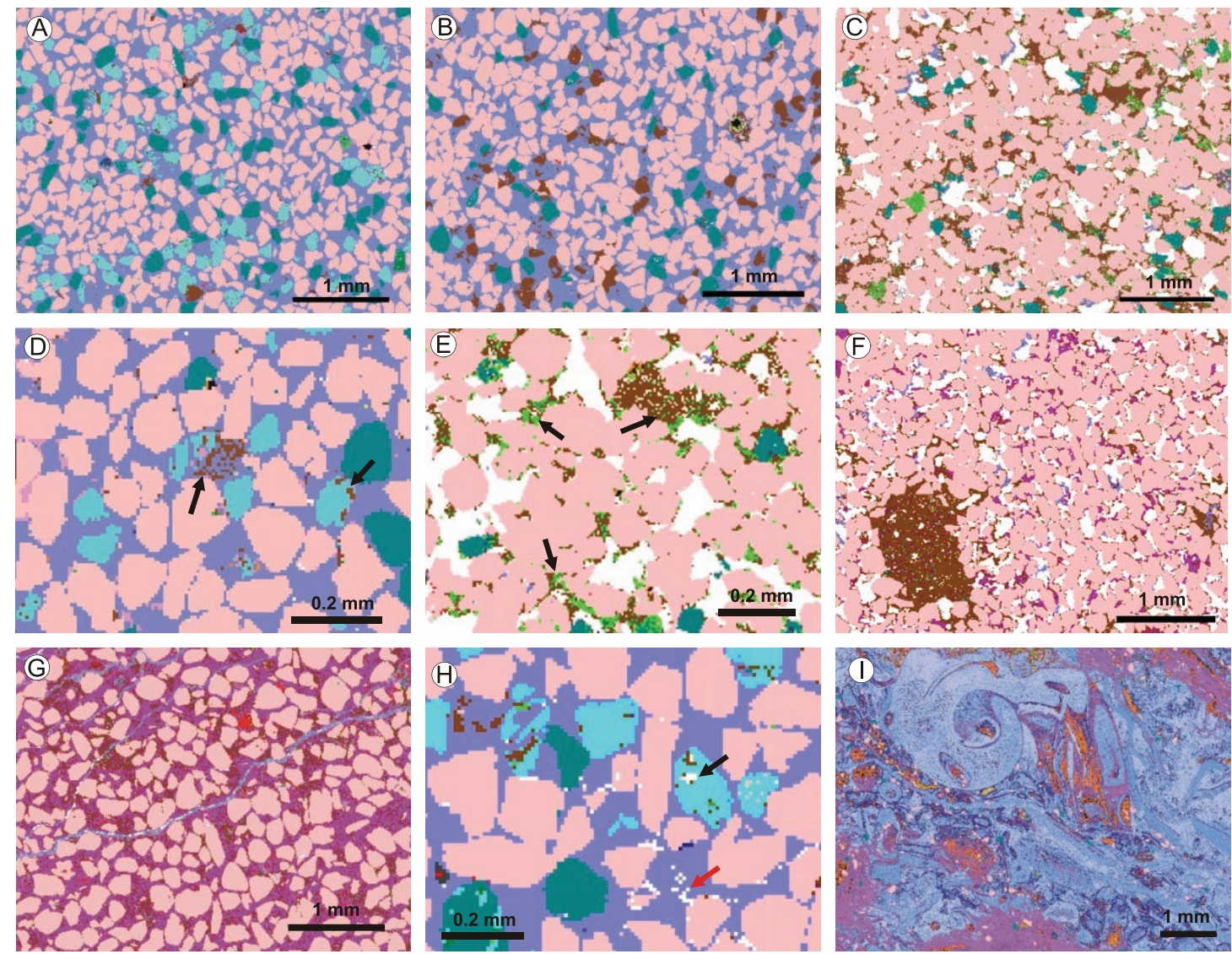

\begin{tabular}{|l}
$\square$ Porosity \\
$\square$ Chlorite
\end{tabular}
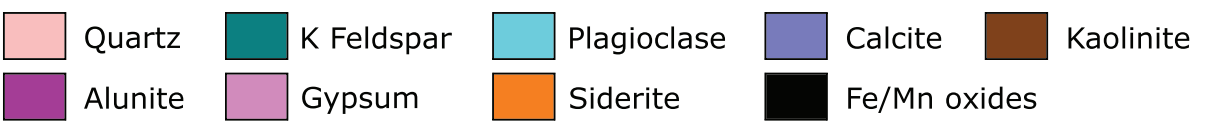

Fig. 7. Images derived from QEMSCAN ${ }^{\circledR}$ analysis. A. Calcite cemented sandstone (Sample JA I-260e). Note the relative abundance of plagioclase grains and rare occurrence of kaolinite. B. Calcite cemented sandstone (Sample JA I-260d). Note the relative abundance and grain shape of kaolinite and the scarcity of plagioclase. C. Porous sandstone (Sample JA I-280c). Note the absence of plagioclase and the deformation of kaolinite to form pseudomatrix. D. Detail image of a calcite-cemented sandstone (Sample JA I-260e). Note the partial transformation of plagioclase by kaolinite (arrows). E. Detail of a porous sandstone (Sample JA I-280c). Note the partial transformation of kaolinite to chlorite (arrows). F. Porous sandstone, partly cemented by alunite (Sample T 10-13). The large kaolinite mass is possibly of depositional origin. G. Sandstone cemented by alunite (Sample T I0-I I). H. Calcite-cemented sandstone (Sample JA I-260e) with some remaining interparticle micro-porosity (red arrow) and minor intragranular micro-porosity (black arrow). I. Limestone (Sample JA I259-I) with abundant gypsum and siderite.

plagioclase grains. Rarely, irregularly shaped kaolinite pockets up to $1.5 \mathrm{~mm}$ in size were observed. Chlorite usually occurs scattered throughout the intergranular area.

Cements

The dominant cement type was calcite. The average amount within all measured sandstone samples was 12.8\% (min. 0.0; max. 38.3). Calcite cement mostly occurs as poikilotopic sparry cements, and in some samples fills the entire pore space; calcite spar is present in various amounts surrounding framework grains. The majority of calcite cements have a homogeneous, bright orange cathodoluminescence (CL) without zoning (Fig. 8).The margins of some quartz grains are replaced by calcite with preserved dust rims indicating the original size of the grains (Fig. 13).

A second cement type, which is locally important, is alunite (Al-K-sulphate). This only occurs in trace amounts in most localities. However in locality 1 , alunite is more abundant and almost completely fills the intergranular space of sample T 10-11 (Fig. 7g).

The third cement type is gypsum. This is of minor importance and only occurred as small patches in a few samples. The maximum amount of gypsum $(1.7 \%)$ occurred in sample T 10-11 from locality 1 , where it dominantly occurs along micro-fractures.

Porosity and permeability of sandstones

The average porosity of all 52 samples calculated from the QEMSCAN ${ }^{\circledR}$ results is $12.3 \%$ (min 0.5 ; $\max 25.4$ ). 


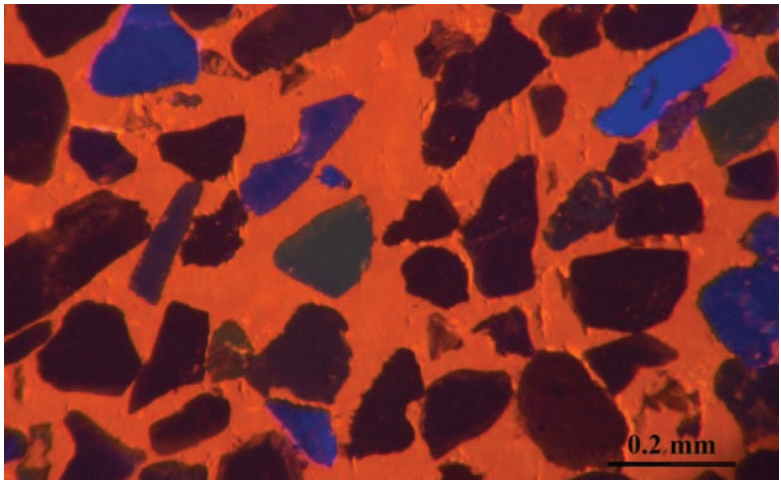

Fig. 8. Cathodoluminescence image of calcitecemented fluvial sandstone. Calcite shows homogeneous bright orange luminescence (Sample JA I260e). Quartz grains are non-luminescent while feldspar displays blue luminescence.

Intergranular porosity is dominant, with trace amounts of intragranular microporosity occurring within altered feldspar grains. Marked variations in porosity can occur between different sandstones. The hard (indurated) sandstone of location 4 (sample series JA 1-260) have on average only $0.8 \%$ porosity, while the friable sandstones from the upper channel at the same locality (sample series JA 1-280) had on average $16.5 \%$ porosity (Table 1 ).

Four sandstone samples were collected with a hand-held corer from the outcrop for conventional porosity and permeability measurements. Two samples from LST 4 from locality 2 yielded permeabilities of $220 \mathrm{mD}$ (25.9\% porosity) and $342 \mathrm{mD}(21.9 \%$ porosity), respectively. Two samples taken from LST 5 at locality 4 yielded permeabilities of $1.9 \mathrm{mD}(8.3 \%$ porosity) and $0.4 \mathrm{mD}(2.5 \%$ porosity), respectively (Fig. 9).

\section{Intergranular volume and compaction of sandstones}

Intergranular volume (IGV) is defined as the sum of intergranular pore space, intergranular cement, and depositional matrix (Paxton et al., 2002). Clay in the samples analysed is most likely derived from the alteration of feldspar grains (see Discussion, below), so IGVs in Table 1 were calculated excluding kaolinite and chlorite. The average IGV of all sandstone samples is 26.2 area-\% (min 7.8; $\max 39.3$ ).

A variable degree of mechanical compaction occurs in the sandstones. In general, more compacted sandstones have less calcite cement. Other evidence of mechanical compaction is the deformation of kaolinite, derived from the alteration of plagioclase to pseudomatrix. Chemical compaction (i.e. pressure dissolution) was observed in sandstone samples with no calcite cement; quartz grains show convex-concave and sutured contacts (Fig. 13). Neither mechanical nor chemical compaction were observed in the limestone samples.

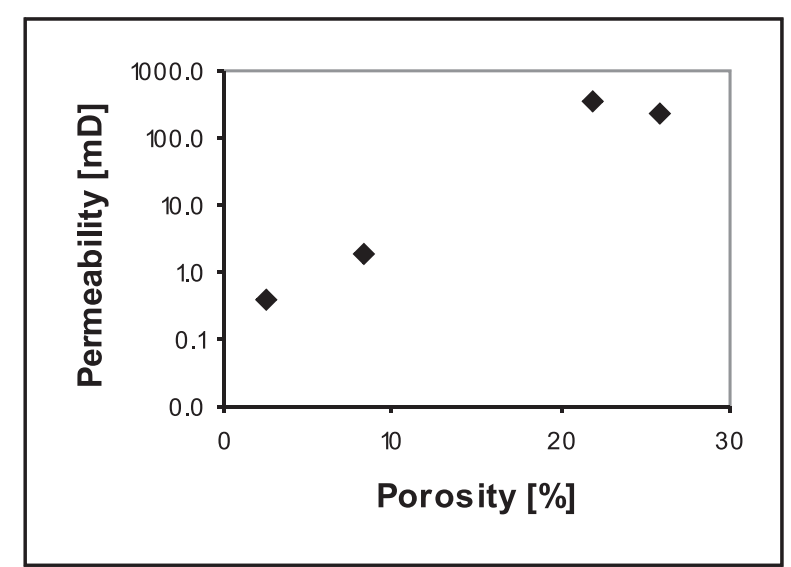

Fig. 9. Porosity versus permeability plot of four fluvial sandstone samples.

Relationships between minerals, porosity and IGV

Some general relationships can be extracted from the QEMSCAN $^{\circledR}$ data (Fig. 10):

- There is a positive relationship between increased calcite cement and higher IGV. Examples come from locality 2 samples. Three samples which were taken from large concretions within the sandstone channel (JA 901-16 to 18) have significantly higher IGVs than the other samples of the JA 901 series.

- There is a correlation between high porosity values and lower amounts of plagioclase. Also, as calcite is the dominant cement, there is a positive correlation between calcite and plagioclase. Examples for this relationship can be seen in samples from locality 4 . The rigid, highly calcite-cemented channel sand (sample series JA 1-260) shows relatively high amounts of plagioclase, while the porous and friable channel sand above is almost devoid of plagioclase (sample series JA 1-280).

- There is an inverse correlation between kaolinite and plagioclase. This relationship was observed in the two channel sands of locality 4 (sample series JA 1260 versus JA 1-280) which are good examples of these relationships.

\section{Microfacies and mineralogy of underlying limestones}

Limestones of locality 3 are dominantly packstones, while those of locality 4 are grainstones containing few small patches of matrix. Components are similar in samples from both localities. Bioclasts are dominantly derived from brachiopods, bryozoans, crinoids and gastropods, with less frequent echinoids, foraminifera, goniatites and rugose corals. Ooids are abundant in some samples and few peloids and extraclasts occur. In the analysed thin sections, no evidence of dissolution of carbonate components was observed. 
Table 2. QEMSCAN ${ }^{\circledR}$ data of limestone samples.

\begin{tabular}{|c|c|c|c|c|c|c|c|c|c|c|c|c|c|c|}
\hline Location & Sample No. & Qtz & K-Fsp & Plag & Calcite & Kaolinite & Chlorite & Siderite & Gypsum & Pyrite & $\begin{array}{l}\text { Fe/Mn } \\
\text { oxides }\end{array}$ & Dolomite & Misc & Porosity \\
\hline 4 & JA 1-259-1 & 2.48 & 0.61 & 0.01 & 78.36 & 0.32 & 0.11 & 3.54 & 12.51 & 0.04 & 0.81 & 0.43 & 0.81 & 0.32 \\
\hline 4 & JA 1-259-2 & 1.63 & 0.35 & 0.00 & 92.63 & 0.10 & 0.03 & 0.70 & 2.59 & 0.00 & 0.12 & 0.13 & 1.72 & 1.30 \\
\hline 4 & JA 1-259-3 & 1.58 & 0.35 & 0.00 & 92.49 & 0.20 & 0.06 & 0.58 & 1.85 & 0.00 & 0.27 & 0.11 & 2.49 & 1.70 \\
\hline 4 & JA 1-259-4 & 37.50 & 3.90 & 0.05 & 49.79 & 4.87 & 0.71 & 0.34 & 0.01 & 0.00 & 0.17 & 0.08 & 2.58 & 1.12 \\
\hline 4 & Average & 10.80 & 1.30 & 0.01 & 78.32 & 1.37 & 0.23 & 1.29 & 4.24 & 0.01 & 0.34 & 0.19 & 1.90 & 1.11 \\
\hline 3 & JA 951-1a & 5.70 & 3.29 & 0.83 & 76.78 & 0.86 & 6.11 & 2.64 & 0.04 & 0.01 & 0.20 & 0.63 & 2.91 & 0.19 \\
\hline 3 & JA 951-1b & 9.87 & 5.72 & 1.46 & 50.21 & 2.04 & 1.74 & 4.54 & 20.81 & 0.41 & 0.37 & 0.38 & 2.45 & 0.65 \\
\hline 3 & Average & 7.79 & 4.51 & 1.15 & 63.50 & 1.45 & 3.92 & 3.59 & 10.42 & 0.21 & 0.29 & 0.50 & 2.68 & 0.42 \\
\hline
\end{tabular}

Mineral volume (area\%)

QEMSCAN $^{\circledR}$ analysis shows that the dominant carbonate mineral is calcite. Siderite is of minor importance and dolomite only occurs in traces (Table 2 ). The amount of quartz grains occurring in the limestones varies considerably from $1.6 \%$ to $37.5 \%$. The amount of gypsum varies from 0.0 to $20.8 \%$.

\section{Carbon and oxygen isotopes}

Stable carbon and oxygen isotopes were measured from calcite cement within the sampled sandstones (11 samples), from bulk rock samples of the limestones which are in contact with sandstones at the base of the channels (six samples), from brachiopod shells (two samples) and calcite cement within brachiopods from the limestones (two samples) (Fig. 12). These can be classified into four groups.

Group 1 (carbonate cements in sandstones): Calcite cement within the sandstones from the channels from localities 2 and 3 has a relatively narrow range of isotopic values; $\delta^{13} \mathrm{C}$ ranges from $-3 \%$ to $6 \%$ and $\delta^{18} \mathrm{O}$ from $-8 \%$ to $-11 \%$. In locality 4 , however, the carbon-isotope values sampled from the calcite cement within the sandstones are significantly lighter and the oxygen-isotopes slightly greater $\left(\delta^{13} \mathrm{C}\right.$ $=-11 \%$ to $-24 \%$; $\delta^{18} \mathrm{O}=-6 \%$ o to $-9 \%$ o).

Group 2 (limestones): Bulk rock isotope values for the limestones show a narrow range of oxygen values $\left(\delta^{18} \mathrm{O}=-7 \%\right.$ to $-10 \%$ o $)$ and carbon values $\left(\delta^{13} \mathrm{C}\right.$ $-2 \%$ to $-11 \%$ o).

Group 3: Brachiopod shells, which are derived from a limestone at locality 3 , have $\delta^{13} \mathrm{C}$ values from $+1 \%$ o to $-1 \%$ and $\delta^{18} \mathrm{O}$ values from $-3 \%$ o to $-4 \%$.

Group 4: Calcite cement from within brachiopods of a limestone layer at locality 3 has a more negative carbon isotope value $\left(\delta^{13} \mathrm{C}=-19 \%\right.$ to $-26 \%$ ).$\delta^{18} \mathrm{O}$ values from both samples are $-8 \%$.

\section{DISCUSSION}

Timing and depth of calcite cement formation

The graph of calcite cement versus IGV (Fig. 10a) shows a positive correlation, indicating that the more calcite cemented sandstones have larger IGV values. Paxton et al. (2002) constructed an IGV versus depth plot based on a large dataset (Fig. 13a), showing that IGV rapidly declines due to mechanical compaction from $40-42 \%$ at the surface to about $28 \%$ at $1500 \mathrm{~m}$, then more slowly to about $26 \%$ at $2500 \mathrm{~m}$. The latter IGV value represents the physical lower limit of mechanical compaction.

In this study, the IGV values of the sandstone samples with the highest amount of calcite cement range between $35 \%$ and $40 \%$. Kaolinite and chlorite are not part of the IGV but are considered as framework grains, as they are probably derived from unstable feldspar (see below). However, rare depositional kaolinite occurs. This can be recognised as large lumps or masses (Fig. 7) and should be included as part of the IGV. The QEMSCAN ${ }^{\circledR}$ analyser cannot differentiate between depositional and diagenetic kaolinite. Visual analysis suggests that the resulting error is small, as analysis of QEMSCAN ${ }^{\circledR}$ images shows that depositional clay occurs very rarely.

A second uncertainty in determining an accurate IGV value occurs because some margins of quartz grains are corroded and replaced by calcite (Fig. 13b). This has the effect of increasing the original IGV. Thin section analysis shows that in most sandstone samples the replacement of quartz by calcite is of minor significance.

Taking into account these minor adjustments, the range of IGV between $35 \%$ and $40 \%$ has been used to estimate the depth of significant calcite cementation by comparison to the IGV-compaction curve of Paxton et al. (2002) (Fig. 13a). This suggests that it is likely that the majority of calcite cementation within the Lower Carboniferous channel sandstones in western Libya occurred within about $100-500 \mathrm{~m}$ of burial. The low stable oxygen isotope values of the calcite cement and the occurrence of early diagenetic kaolinite suggest the influence of meteoric pore-waters (see below), which confirms that calcite cement precipitated during very shallow burial.

Samples with very low or no calcite cement have lower IGV values, ranging between $17 \%$ and $25 \%$. As mechanical compaction can reach a minimum of about $26 \% \mathrm{IGV}$, additional porosity loss in these uncemented sandstone samples was probably due to 

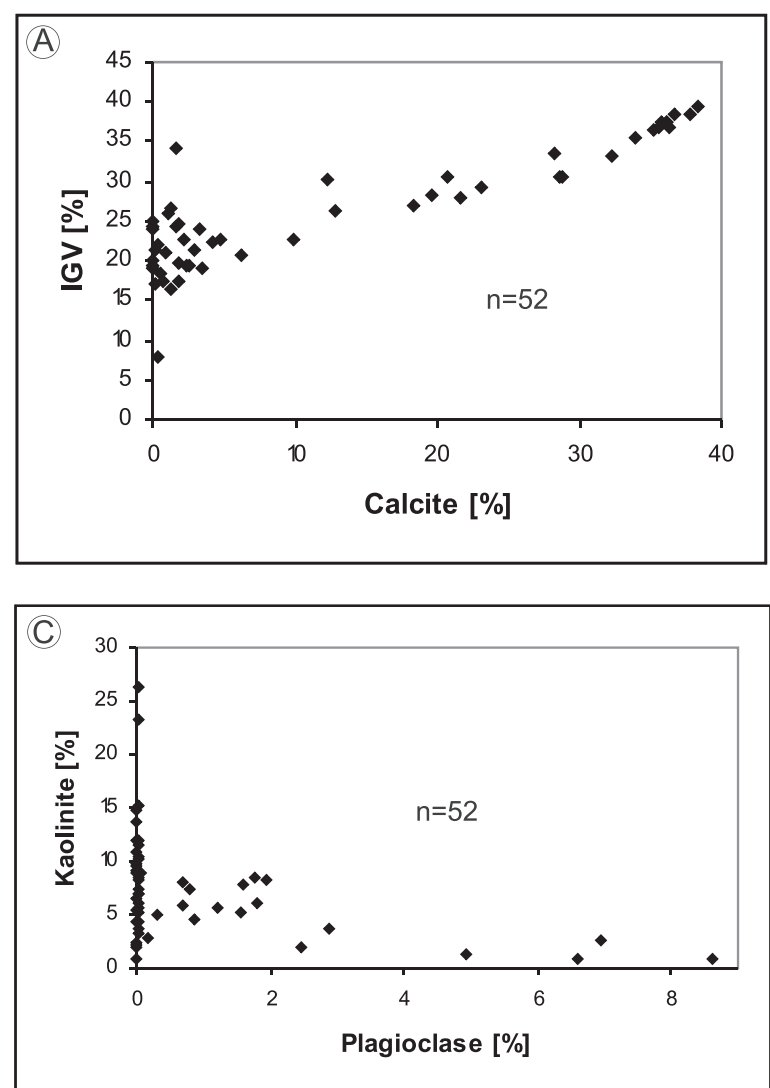

further compaction associated with pressure dissolution. For this to occur, burial depth must have exceeded $2500 \mathrm{~m}$, according to a comparison with the IGV-compaction curve of Paxton et al. (2002).

The fact that pervasively calcite-cemented sandstones in the outcrops commonly occur in the form of concretions (Fig. 11), while porous sandstones are present between concretions, indicates that latestage outcrop weathering probably had a minor effect on the measured porosity. Concretions grew during eodiagenesis; after uplift and exposure, the porous sandstones were weathered and removed.

\section{Clay mineral formation \\ Kaolinite}

In the highly cemented sample series JA 1-260 from locality 4, one sample (JA 1-260d) had a lower content of plagioclase compared to the other four (Table 1). In the same sample, the kaolinite content is much higher than in the other four samples, which were taken from the same sandstone. Kaolinite here appears to be a framework grain of about the same size and shape as plagioclase in the other samples (Fig. 7b). In addition, tiny patches of kaolinite were observed within plagioclase grains. These observations indicate that the majority of kaolinite was derived from the diagenetic alteration of plagioclase. This is supported by the plagioclase-kaolinite plot derived from all 52 sandstone samples which shows a negative correlation (Fig. 10c).

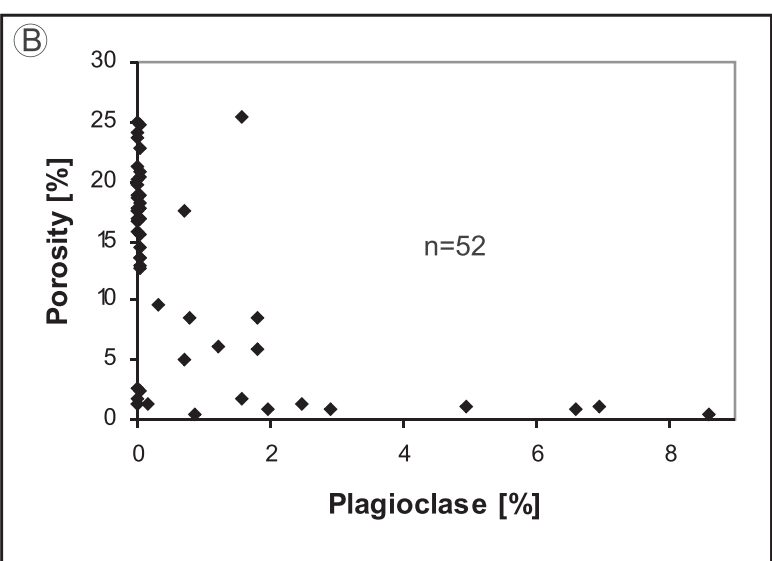

Fig. I0. A. Plot shows a positive correlation between intergranular volume (IGV) and calcite cement volume. B. Plot shows a negative correlation between porosity and the amount of plagioclase. C. Plot shows a negative correlation between kaolinite and plagioclase. The database for each plot comprises $\mathbf{5 2}$ samples from fluvial channel sandstones from the four investigated localities (see Table I).

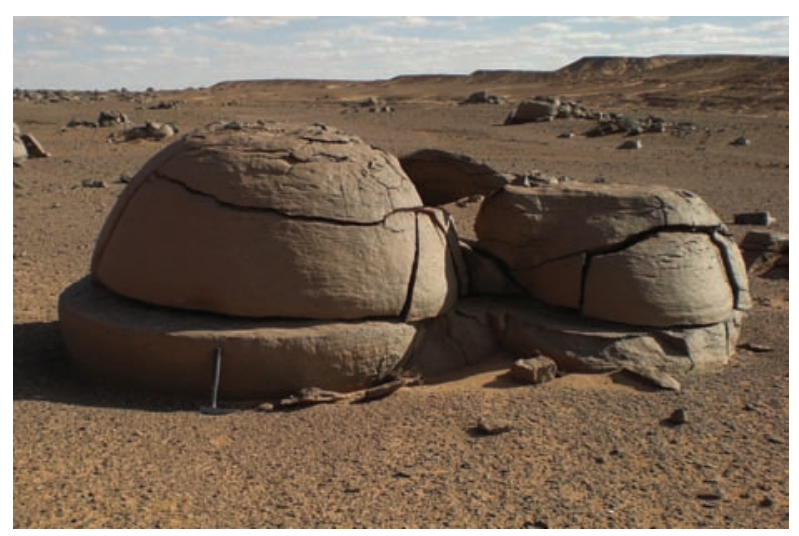

Fig. I I. Field photograph of outcropping "cannonball" concretions which occur within Viséan sandstones of LST 4, western Tinedhan Anticline.

The alteration of feldspar to kaolinite is a typical eodiagenetic reaction and requires humid climatic conditions, allowing low-pH ground waters to infiltrate continental sediments (Emery et al., 1990; Worden and Morad, 2003). The Lower Carboniferous sandstones sampled for this study are interpreted to be fluvial sandstones deposited in incised channels during a period of regional subaerial exposure (Fröhlich et al., in press). The development of kaolinite suggests that these sandstones underwent meteoric diagenesis.

Controlling factors on meteoric diagenesis include the amount of annual precipitation and the amount of detrital feldspar originally in the sandstones. In 


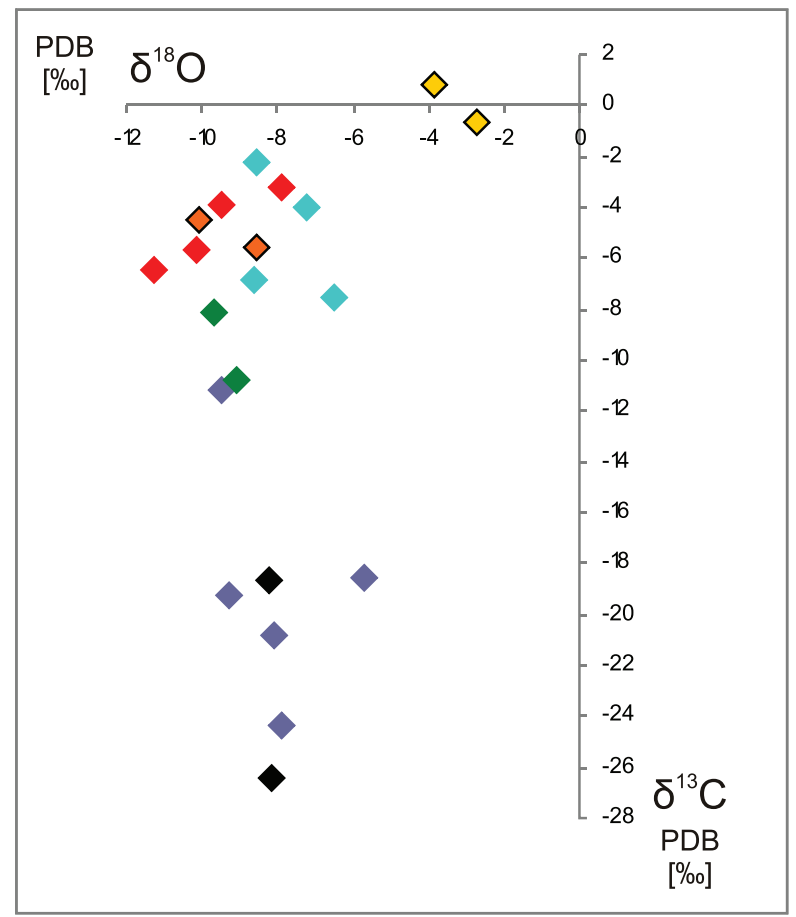

addition, the rate of fluid flow in the sandbody is an important control on the amount and distribution pattern of kaolinite (Worden and Morad, 2003). In the sandstones studied, which have a fairly uniform fine-grained texture, fluid flow is dominantly influenced by the amount of calcite cement. As discussed above, cementation took place during early eodiagenesis. In the highly calcite-cemented samples, there is only partial alteration of plagioclase to kaolinite. In the porous samples, plagioclase is almost absent and the structure of the kaolinite suggests that most of this feldspar has been altered to kaolinite. This relationship with the early calcite cements suggests that the transformation of plagioclase to kaolinite started at very shallow burial depths.

At burial depths of between $2.5 \mathrm{~km}$ and $5 \mathrm{~km}$, kaolinite is gradually transformed to dickite, i.e. it loses the vermicular habit and forms thicker, blocky crystal forms (Beaufort et al., 1998). The QEMSCAN $^{\circledR}$ analyser cannot differentiate between these two clay minerals because they have identical chemical compositions. SEM studies of the crystal habits of kaolinite in eight selected sandstone samples, however, show that the vermicular forms predominate in the sandstones studied; dickite crystals were not observed.

Previous work in other basins has shown that in sandstones which include K-feldspar, kaolinite becomes unstable and is transformed to illite at temperatures between $120^{\circ} \mathrm{C}$ and $140^{\circ} \mathrm{C}$ (Bjørlykke and Aagaard, 1992; Ehrenberg and Nadeau, 1989). $\mathrm{K}$-feldspar is present in sandstone samples from this study, but illite is absent. This would suggest that temperatures affecting the Lower Carboniferous strata

\begin{tabular}{|c|c|c|}
\hline & $\begin{array}{l}\text { Brachiopod shells } \\
\text { Location } 3\end{array}$ & $\begin{array}{l}\text { Calcite cement within } \\
\text { sandstone channels: }\end{array}$ \\
\hline & $\begin{array}{l}\text { Bulk rock } \\
\text { limestone Loc. } 3\end{array}$ & $\diamond \quad$ Locality 2 \\
\hline & Bulk rock & Locality 3 \\
\hline & $\begin{array}{l}\text { Calcite cement } \\
\text { within brachiopods } \\
\text { Location } 3\end{array}$ & Locality 4 \\
\hline
\end{tabular}

Fig. I 2. Cross-plot of oxygen and carbon isotopes for selected samples. See text for discussion.

of the Tinedhan Anticline probably did not exceed $140^{\circ} \mathrm{C}$. A present-day geothermal gradient map for the Ghadames Basin (Underdown and Redfern, 2008) shows values of $4^{\circ} \mathrm{C} / 100 \mathrm{~m}$ in the study area. Assuming a comparable geothermal gradient throughout burial, the Lower Carboniferous succession in this locality probably did not exceed $3.5 \mathrm{~km}$ burial depth.

As quartz grains are much more rigid than kaolinite, mechanical compaction resulted in severe deformation of the clays and left them scattered throughout the sandstone as pseudomatrix. The original grain shape of the kaolinite after transformation from plagioclase is only retained in calcite-cemented samples which have not suffered significant compaction due to the presence of early cements (Fig. 7).

The degradation of feldspar to clays alters the mineralogy of the sandstones. Sandstone samples in this study were classified as arkoses, subarkoses and quartzarenites (Fig. 5). Considering that, especially in porous sandstones, many of the feldspar grains were transformed to clay during diagenesis, it is likely that the sandstones classified as quartzarenites were originally deposited as subarkoses or even arkoses.

\section{Chlorite}

According to Worden and Morad (2003), chlorite does not form during eodiagenesis but may develop due to recrystallisation of eodiagenetic clay minerals such as kaolinite during mesodiagenesis. If chlorite is found in soils or in deposits which have not undergone burial diagenesis, it must be of depositional origin (Wilson, 1999). The QEMSCAN ${ }^{\circledR}$ images of the sandstone samples in this study show that chlorite often occurs 

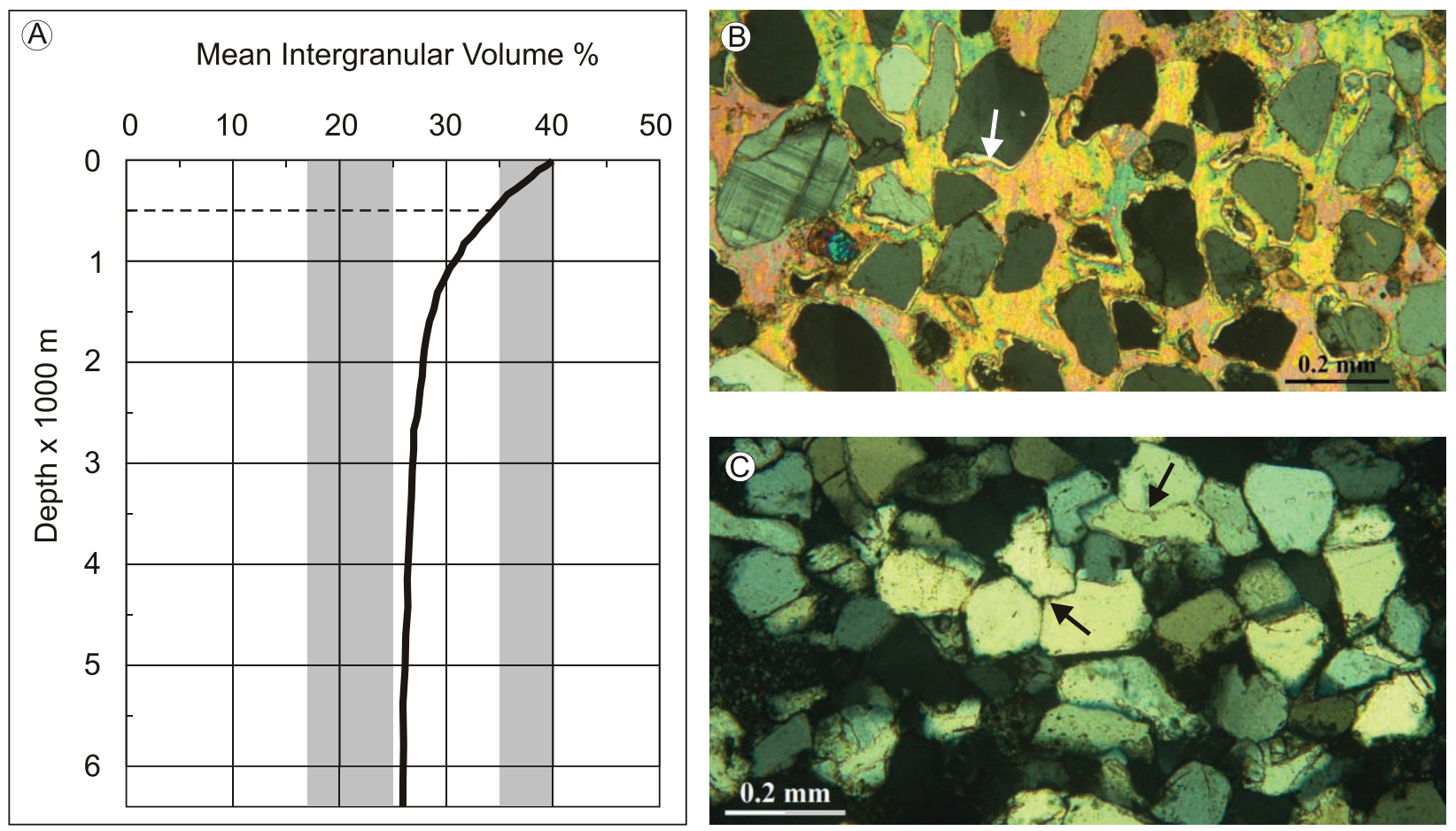

Fig. 13. A. Intergranular volume (IGV) compaction curve (modified from Paxton et al., 2002), showing a general reduction in IGV in uncemented sandstones due to compaction. Grey zones indicate maximum IGV of highly-calcite cemented sandstones and minimum IGV of uncemented sandstones for this study (see Fig. I0A). B. Thin section image (crossed nicols) showing a sandstone with high IGV (sample JA I-260e), which was cemented by calcite before compaction. Note that the margins of some quartz grains are replaced by calcite (arrow). C. Thin section image (crossed nicols) of an uncemented sandstone with low IGV (sample JA 90 I-14). Note convex-concave and sutured contacts (arrows) between quartz grains due to compaction.

together with kaolinite (Fig. 7e); also, small traces of chlorite occur within kaolinite. This suggests that chlorite is of diagenetic origin, probably derived from the alteration of kaolinite, and not of depositional origin. The temperature at which chloritization of kaolinite occurs was $100^{\circ} \mathrm{C}$ in Triassic red-bed sandstones offshore Norway (Worden and Morad, 2003); other studies suggest higher temperatures (e.g. Boles and Franks, 1979). With an assumed geothermal gradient of $4^{\circ} \mathrm{C} / 100 \mathrm{~m}$, the $100^{\circ} \mathrm{C}$ isotherm occurs at between 2 and $2.5 \mathrm{~km}$ depth. The chloritization of kaolinite therefore suggests a minimum burial depth of $2-3 \mathrm{~km}$ for Lower Carboniferous rocks in the Tinedhan Anticline area.

\section{Source of calcite cement}

To investigate the origin of the calcium and carbonate of the calcite cement within the sandstones, it is useful to consider the depositional facies and the relative timing of cementation. The calcite-cemented sandstones are interpreted to be fluvial in origin, deposited in channels that cut into marine deposits. The latter deposits mainly consist of alternating mudstones and sandstones, with a few limestone layers up to $0.5 \mathrm{~m}$ thick (Fröhlich et al., in press). These limestones are in contact with two of the four investigated fluvial channel sandbodies, and are thus a possible source of calcium and carbon. The influence of meteoric pore waters during calcite precipitation is also likely, because: (1) fluvial sediments were subaerially exposed during deposition; (2) calcite cementation occurred during very shallow burial; and (3) kaolinite, which is abundant in the sandstones, is a common diagenetic product of meteoric pore waters (see above).

Carbonate ${ }^{13} \mathrm{C}$ values within brachiopod shells from the limestones are around $0 \%$ (Fig. 12) and are thus of normal marine origin (e.g. Keith and Weber, 1964). The strongly negative $\delta^{13} \mathrm{C}$ values of the calcite cement within brachiopods indicate a major contribution from organic carbon (Irwin et al., 1977). The bulk rock $\delta^{13} \mathrm{C}$ values, which represent a mixture of isotope signals from shells, inorganic carbonate components and cement, plot between the values of the brachiopod shells and the cement. Calcite cement of the channel sandstones of localities 2 and 3 have $\delta^{13} \mathrm{C}$ values between -3 and $-7 \%$, and thus have similar values to bulk-rock samples from the limestones. Dissolution of the limestones would, however, have to take place early during burial, which is possible due to the low $\mathrm{pH}$ of the pore waters (Morad, 1998). However, there was no evidence in the analysed thin sections that carbonate components were partly or completely dissolved. Pressure dissolution of limestones is unlikely to have contributed calcium carbonate, as the calcite cementation occurred during 


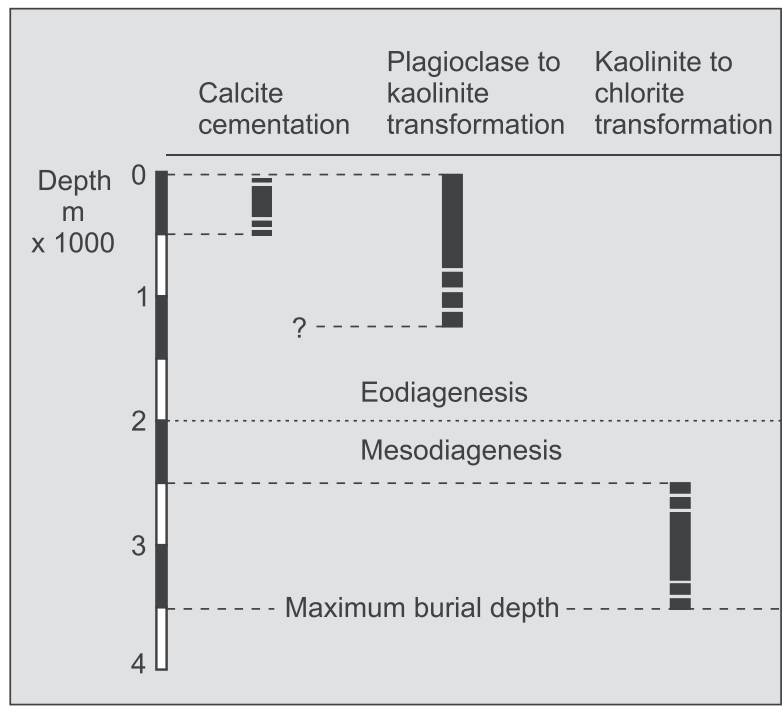

Fig. 14. Summary of the main diagenetic events and their relation to burial depth.

very shallow burial.

Total dissolved carbon in meteoric water can vary widely in isotopic composition, as the carbon can be derived from various sources. Atmospheric $\mathrm{CO}_{2}$, however, has average $\delta^{13} \mathrm{C}$ values of around $-7 \%$ (Hoefs, 1997). Hudson (1975) observed that cementation of limestones with meteoric waters shifted the $\delta^{13} \mathrm{C}$ values from $0 \%$ to about $-6 \%$. Carbon from meteoric water may therefore have contributed to the calcite cement in sandstones of localities 2 and 3.

Values of $\delta^{13} \mathrm{C}$ from calcite cement of the sandstone of locality 4 (LST 5) are much more negative compared to those of localities 2 and 3 (LST 4), which indicates that carbon derived from organic matter contributed to the calcite here.

Calcite cement $\delta^{18} \mathrm{O}$ values depend on the temperature during precipitation and on the $\delta^{18} \mathrm{O}$ values of the ambient water (e.g. Sanyal et al., 2005). As most of the calcite crystallised very early during eodiagenesis, higher temperatures related to burial probably had little effect on the oxygen isotope composition and the local isotope signal of the ground water was the dominant control. The $\delta^{18} \mathrm{O}$ values of the calcite cement from the channel sandstones of around $-9 \%$ thus indicate a meteoric signal.

Considering all the above factors, it can be concluded that meteoric water must have been the dominant source of calcium and carbonate for the calcite cement.

\section{Alunite and gypsum cement \\ Alunite}

This mineral $\left[\mathrm{K} \mathrm{Al}_{3}\left(\mathrm{SO}_{4}\right)_{2}(\mathrm{OH})_{6}\right]$ has been described (Goldbery, 1978) as an early diagenetic precipitate in Jurassic clays in Israel, derived from the dissolution of kaolinite in fluvial deposits. Blanco et al. (2008) found alunite in Late Cretaceous alluvial palaeosols in the Duero Basin, Spain. They concluded that alunite precipitated together with kaolinite in low-pH waters during wet periods in a seasonal tropical climate.

In the present study at locality 1 , sample $\mathrm{T}$ 10-11 has a high IGV and contains pore-filling alunite, which suggests the mineral must have precipitated in the sandstones during early diagenesis (Fig. 7g). The sources of potassium and aluminium cannot be determined with the available data.

\section{Gypsum}

As a cement within sandstones, gypsum is of minor importance. Where it occurs along microfractures as in sample T $10-11$, it is possibly a recent precipitate which developed after inversion and uplift of the rocks during outcrop exposure.

In some of the limestone samples, however, which are derived from layers below the channel sandstones, the amount of gypsum cement is significant (Table 2, Fig. 7i). These limestone layers were deposited in a shallow-marine environment before major regressions and the development of a fluvial system. It is likely that a seasonal climate prevailed during the Lower Carboniferous in Libya with alternating dry and wet periods (Raymond et al., 1985). Evaporation during the dry periods may have caused the precipitation of gypsum.

\section{CONCLUSIONS}

In addition to normal compaction, three main diagenetic events (Fig. 14) controlled porosity and permeability of the Lower Carboniferous fluvial sandstones in the study area:

(1) Kaolinitization of plagioclase began before calcite cementation, and thus during early eodiagenesis, in the presence of meteoric pore-waters. Kaolinite first retained the grain shape of plagioclase but was deformed to pseudomatrix during compaction. This resulted in a reduction of porosity and permeability.

(2) Calcite cement reduced the pore space during shallow burial. Calcite cementation occurred dominantly in the uppermost $500 \mathrm{~m}$ with the generation of tight concretions up to $2 \mathrm{~m}$ in diameter, or as dispersed cements throughout the intergranular space. Calcium and carbonate are most likely derived from meteoric waters and not from the thin limestone layers which are rarely intercalated in the dominantly siliciclastic succession.

(3) Chloritization of kaolinite occurred during mesodiagenesis, probably at a minimum burial depth of approximately $2.5 \mathrm{~km}$. As this is a replacement process of one clay mineral by another within the 
intergranular space, the porosity and permeability were little affected.

Outcrop, thin section and QEMSCAN analyses indicate that the cementation observed in the tight fluvial sandstones predominantly occurs in the form of concretions which do not produce continuous permeability barriers. Despite the reduction of porosity and permeability due to continued diagenesis with burial, the average porosity of the fluvial sandstone samples studied was $12 \%$. Permeability measurements of four selected samples indiacte a maximum of $342 \mathrm{mD}$, which suggests that the pseudomatrix did not significantly reduce permeability.

The analysis of diagenetic clay minerals in the fluvial channel sandstones indicate that Lower Carboniferous deposits at the Tinedhan Anticline were buried to a minimum depth of about $2.5 \mathrm{~km}$, confirmed by the compaction data, and to a maximum depth of approximately $3.5 \mathrm{~km}$.

\section{ACKNOWLEDGEMENTS}

We are indebted to Woodside Energy N.A. for logistical assistance in Libya. Discussion on the outcrop with S. Lang, T. Rehill (both Woodside Energy) and S. Bodin (NARG, Manchester) improved the study. Intellection (Abergele, Wales) performed the QEMSCAN ${ }^{\circledR}$ analysis as part of their academic support programme, which is gratefully acknowledged. Funding for this study came from the NARG Consortium (Hess, BG Group, ConocoPhillips, Woodside, Repsol, Anadarko, RWE, Wintershall, Pluspetrol and Maersk). Journal reviews by Peter Turner (Cuadrilla Resources Ltd.) and Rob Raine (Ichron Ltd) are acknowledged with thanks.

\section{REFERENCES}

ABOUESSA, A. and MORAD, S., 2009. An integrated study of diagenesis and depositional facies in tidal sandstones: the Hawaz Formation (Middle Ordovician), Murzuq Basin, Libya. Journ. Petrol. Geol., 32 (I), 39-66.

ABUGARES, Y.I., 2003. The Petroleum Geology of the Palaeozoic Clastics of the Murzuq Basin, Al'Atshan Saddle and the Southern Part of the Ghadames Basin, Libya. In: SALEM, M.J. and OUN, K.M. (Eds.): The Geology of Northwest Libya. Earth Science Society of Libya, 213-244.

ALEM, N.,ASSASSI, S., BENHEBOUCHE, S. and KADI, B., 1998. Controls on hydrocarbon occurrence and productivity in the F6 reservoir, Tin Fouye-Tabankort area, NW Illizi Basin. In:MacGREGOR, D.S., MOODY, R.T.J. and CLARK-LOWES, D.D. (Eds.): Petroleum Geology of North Africa. Geological Society, London, Special Publication, I32, I75-186.

BEAUFORT, D., CASSAGNABERE, A., PETIT, S., LANSON, B., BERGER, G., LACHARPAGNE, J.C. and JOHANSEN, H., 1998. Kaolinite-to-dickite reaction in sandstone reservoirs. Clay Minerals, 33, 297-316.

BELHAJ, F., 2000. Carboniferous and Devonian Stratigraphy the M'rar and Tadrart Reservoirs, Ghadames Basin, Libya.
In: SOLA, M.A. and WORSLEY, D. (Eds.): Geological Exploration in Murzuq Basin. Elsevier Science B.V., II7142.

BJØRLYKKE, K. and AAGAARD, P., 1992. Clay minerals in North Sea sandstones. In: HOUSEKNECHT, D.W. and PITTMAN, E.D. (Eds.): Origin, Diagenesis and Petrophysics of Clay Minerals in Sandstones. SEPM Spec. Publ., 47, 65-80.

BLANCO, J.A.,ARMENTEROS, I. and HUERTA, P., 2008. Silcrete and alunite genesis in alluvial palaeosols (late Cretaceous to early Paleocene, Duero basin, Spain). Sedimentary Geology, 2I I, I-II.

BOLES, J.R. and FRANKS, S.G., 1979. Clay diagenesis in Wilcox sandstones off southwest Texas: implications of smectite diagenesis on sandstone cementation. Journal of Sedimentary Research, 49, 55-70.

BOOTE, D.R.D., CLARK-LOWES, D.D. and TRAUT, M.W., 1998. Palaeozoic petroleum systems of North Africa. In: MacGREGOR, D.S., MOODY, R.T.J. and CLARK-LOWES, D.D. (Eds.): Petroleum Geology of North Africa. Geological Society, London, Special Publication, I32, 7-68.

CARR, I.D., 2002. Second-order sequence stratigraphy of the Palaeozoic of North Africa. Journal of Petroleum Geology, 25, 259-280.

DAVIDSON, L., BESWETHERICK, S., CRAIG, J., EALES, M., FISHER,A., HIMMALI,A., JHO, J., MEJRAB, B. and SMART, J., 2000. The structure, stratigraphy and petroleum geology of the Murzuq Basin, southwest Libya. In: SOLA, M.A. and WORSLEY, D. (Eds.): Geological Exploration in Murzuq Basin. Elsevier Science B.V., 295-320.

ECHIKH, K., 1998. Geology and hydrocarbon occurrences in the Ghadames Basin,Algeria,Tunisia, Libya. In:MacGREGOR, D.S., MOODY, R.T.J. and CLARK-LOWES, D.D. (Eds.): Petroleum Geology of North Africa. Geological Society, London, Special Publication, I32, 109-129.

EHRENBERG, S.N. and NADEAU, P.H., 1989. Formation of diagenetic illite in sandstones of the Garn Formation, Haltenbanken area, mid-Norwegian continental shelf. Clay Minerals, 24, 233-253.

EMERY, D., MYERS, K.J. andYOUNG, R., I 990.Ancient subaerial exposure and freshwater leaching in sandstones. Geology, I8, II78-II8I.

FRÖHLICH, S., PETITPIERRE, L., REDFERN, J., GRECH, P., BODIN, S. and LANG, S., in press. Sedimentological and sequence stratigraphic analysis of Carboniferous deposits in western Libya: recording the sedimentary response of the northern Gondwana margin to climate and sea-level changes.Journal of African Earth Sciences. http://dx.doi.org/ 10.1016/j.jafrearsci.2009.09.007.

GOLDBERY, R., 1978. Early diagenetic, nonhydrothermal Naalunite in Jurassic flint clays, Makhtesh Ramon, Israel. GSA Bulletin, 89, 687-698.

GRUBIC,A., DIMITRIJEVIC, M., GALECIC, M., JAKOVLJEVIC, Z., MOMARNICKI, S., PROTIC, D., RADULOVIC, P. and RONCEVIC, G., I 99I. Stratigraphy of western Fezzan (SW Libya). In:SALEM, M.J. and BELAID, M.N. (Eds.):The Geology of Libya IV.Academic Press, I529-I564.

GUIRAUD, R., BOSWORTH, W., THIERRY, J. and DELPLANQUE,A., 2005. Phanerozoic geological evolution of Northern and Central Africa: An overview. Journal of African Earth Sciences, 43, 83-I43.

HOEFS, J., 1997. Stable Isotope Geochemistry. Springer, Berlin, $201 \mathrm{pp}$.

HUDSON,J.D., 1975. Carbon Isotopes and Limestone Cement. Geology, 3, 19-22.

IRWIN, H., CURTIS, C. and COLEMAN, M., I977. Isotopic evidence for source of diagenetic carbonates formed during burial of organic-rich sediments. Nature, 269, $209-$ 213.

KEITH, M.L. and WEBER, J.N., I 964. Isotopic composition and environmental classification of selected limestones and 
fossils. Geochim. Cosmochim. Acta, 28, |787-|8|6.

LELUBRE, M., 1948. La Paleozoique du Fezzan sudoriental. Compte Rendus Soc. Geol. France, 18, 79-8I.

LELUBRE, M., 1952. Apercu sur la geologie du Fezzan. Travaux Recent des Collaborateurs. Bull. Serv. Carte. Geol. Algerie, 3, $109-148$.

MBRIDE, E.F., 1963. A classification of common sandstones. Journal of Sedimentary Research, 33, 664-669.

McBRIDE, E.F and MILLIKEN, K.L., 2006. Giant calcitecemented concretions, Dakota Formation, central Kansas, USA. Sedimentology, 53, 1161-1179.

MENNING, M.,ALEKSEEV,AS., CHUVASHOV, B.I., DAVYDOV, V.I., DEVUYST, F.X., FORKE, H.C., GRUNT, T.A., HANCE, L., HECKEL, P.H., IZOKH, N. G., JIN, Y. G., JONES, P. J., KOTLYAR, G. V., KOZUR, H. W., NEMYROVSKA, T.I., SCHNEIDER, J.W., WANG, X.D., WEDDIGE, K., WEYER, D., WORK, D.M., 2006. Global time scale and regional stratigraphic reference scales of Central and West Europe, East Europe, Tethys, South China, and North America as used in the Devonian-Carboniferous-Permian Correlation Chart 2003 (DCP 2003). Palaeogeogr., Palaeoclimatol. Palaeoecol., 240(I-2), 3I8-372.

MERGL, M. and MASSA, D., 2000. A Palaeontological Review of the Devonian and Carboniferous Succession of the Murzuq Basin and the Djado Sub-Basin. In: SOLA, M.A. andWORSLEY,D. (Eds.), Geological Exploration in Murzuq Basin. Elsevier Science B.V., 4I-88.

MORAD, S., 1998. Carbonate cementation in sandstones: distribution patterns and geochemical evolution. In: MORAD, S. (Ed.): Carbonate Cementation in Sandstones. Int. Ass. Sediment. Spec. Publ., 26, I -26.

MORAD, S., KETZER, J.M. and DE ROS, L.F., 2000. Spatial and temporal distribution of diagenetic alterations in siliciclastic rocks: implications for mass transfer in sedimentary basins. Sedimentology, 47 (Suppl. I), 95-I20.

PAXTON, S.T., SZABO, J.O., AJDUKIEWICZ, J.M. and KLIMENTIDIS, R.E., 2002. Construction of an intergranular volume compaction curve for evaluating and predicting compaction and porosity loss in rigid-grain sandstone reservoirs. AAPG Bulletin, 86, 2047-2067.

RAYMOND,A., PARKER,W.C. and TOTMAN PARRISH,.., 1985. Phytogeography and palaeoclimate of the Early Carboniferous. In:TIFFNEY, B.H. (Ed.), Geological Factors and the Evolution of Plants. Yale University Press, New Haven, 169-222.

SANYAL, P., BHATTACHARYA, S.K. and PRASAD, M., 2005. Chemical diagenesis of Siwalik sandstone: Isotopic and mineralogical proxies from Surai Khola section, Nepal. Sedimentary Geology, 180, 57-74.

SCOTESE, C.R., 2000. PALEOMAP project. www.scotese.com. UNDERDOWN, R. and REDFERN, J., 2008. Petroleum generation and migration in the Ghadames Basin, North Africa: A two-dimensional basin-modeling study. AAPG Bulletin, 92, 53-76.

WILSON, M.J., 1999. The origin and formation of clay minerals in soils: past, present and future perspectives. Clay Minerals, 34, 7-25.

WORDEN, R.H. and MORAD, S., 2003. Clay minerals in sandstones: controls on formation, distribution and evolution. In:WORDEN, R.H. and MORAD, S. (Eds.): Clay Mineral Cements in Sandstones. Int.Assoc. Sedimentol. Spec. Publ., 34, 3-4I.

WRIGHT,V.P., 1990. Equatorial aridity and climatic oscillations during the Early Carboniferous, southern Britain. Journ. Geol. Soc., Lond., I47, 359-363. 